\title{
Radio-isotopic age and biostratigraphic position of a lower Badenian tuffite from the western Polish Carpathian Foredeep Basin (Cieszyn area)
}

\author{
Krzysztof BUKOWSKI ${ }^{1, *}$, Karin SANT ${ }^{2}$, Monika PILARZ ${ }^{1}$, Klaudia KUIPER $^{3}$ and Małgorzata GARECKA ${ }^{4}$ \\ 1 Faculty of Geology, Geophysics and Environmental Protection, AGH University of Science and Technology, al. \\ A. Mickiewicza 30, 30-059 Kraków, Poland \\ 2 Utrecht University, Paleomagnetic Laboratory Fort Hoofddijk, Department of Earth Sciences, Utrecht, The Netherlands \\ 3 VU University Amsterdam, Faculty of Sciences, De Boelelaan 1085, 1081 HV Amsterdam, The Netherlands \\ 4 Polish Geological Institute - National Research Institute, Skrzatów 1, 31-560 Kraków, Poland
}

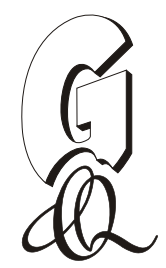

\begin{abstract}
Bukowski, K., Sant, K., Pilarz, M., Kuiper, K., Garecka, M., 2018. Radio-isotopic age and biostratigraphic position of a lower Badenian tuffite from the western Polish Carpathian Foredeep Basin (Cieszyn area). Geological Quarterly, 62 (2): 303-318, doi: 10.7306/gq.1402

The early Badenian interval in the Central Paratethys realm is characterized by a major marine transgression into the Pannonian and Carpathian Foredeep basins. In the western part of the Polish Carpathian Foredeep, Badenian sedimentation started generally with conglomerates (Dębowiec Formation) passing into a thick succession of claystones and mudstones with rare sandstone interbeds (Skawina Formation). Profiles containing a full sequence of lower Badenian strata are relatively rare, and are mainly known from boreholes. In this paper, we present new results on samples taken from such a borehole (Kaczyce K2/07) located near the town of Cieszyn. We focus on reconstructing the chronology of the lower Badenian marine sediments at the beginning of the transgression in the Carpathian Foredeep (lower Skawina Fm.) using radio-isotopic dating $\left({ }^{40} \mathrm{Ar} /{ }^{39} \mathrm{Ar}\right)$ of a volcanoclastic layer (tuff and tuffite) and biostratigraphy of calcareous nannoplankton and foraminifera. The weighted mean ${ }^{40} \mathrm{Ar} /{ }^{39} \mathrm{Ar}$ age for sanidine separates from the tuff provided an age of $14.27 \pm 0.03 \mathrm{Ma}$. This age is consistent with the NN5 and MNN5a nannofossil zones determined in this study. Our foraminiferal assemblages show that the basal beds of the Skawina Formation up to the tuffites correspond to the Orbulina suturalis-Praeorbulina glomerosa Zone (according to Cicha et al., 1975) and cover the interval of the Lower Lagenidae Zone-lowermost Upper Lagenidae Zone (Grill, 1941). The petrographic data from the tuffite allow correlation of the tuffite from the Kaczyce K2/07 borehole to the level of the Chełmek Tuffite Bed (Alexandrowicz, 1997) providing a regional correlation horizon for future studies.
\end{abstract}

Key words: Miocene, Badenian, Carpathian Foredeep, tuffites, ${ }^{40} \mathrm{Ar} /{ }^{39} \mathrm{Ar}$ dating, biostratigraphy.

\section{INTRODUCTION}

The Paratethys was an autonomous zone that included a chain of marine basins extending at its widest from the Alpine-Carpathian region to the modern Aral Sea during Oligocene to Miocene times. The semi-restricted basins were periodically connected with the Mediterranean, the Indo-Pacific Ocean and the Atlantic Ocean (Rögl and Steininger, 1983; Rögl, 1998, 1999). The Paratethys is usually divided into a Western, Central and Eastern segment (e.g., Seneš et al., 1961).

The regional time scale of the Central Paratethys is mostly based on endemic fossil assemblages and its stage boundaries are commonly correlated with the third-order sea level cycles (e.g., Haq et al., 1988) and/or the sequence stratigraphic cycles

* Corresponding author, e-mail: buk@agh.edu.pl

Received: January 5, 2018; accepted: February 9, 2018; first published online: March 26, 2018
(Hardenbol et al., 1998) and proposed by Piller et al., (2007) or Harzhauser and Piller (2007). Recent studies have shown that the lack of independent age constraints may lead to inconsistent palaeogeographic reconstructions (Kovač et al., 2017a; Sant et al., 2017).

This paper focuses on tuffites of the regional Badenian stage, corresponding to the Langhian and early Serravallian stages. The early Badenian was characterized by a diachronous marine transgression that gradually expanded from the west to the south-east of the Central Paratethys realm (Rögl, 1998, 1999). By the late Langhian, water covered the Carpathian Foredeep and most of the Pannonian, Transylvanian, and Getic basins. It likely also connected with the Eastern Paratethys (Hamor and Halmai, 1988; Rögl, 1999; Fig. 1A).

The widespread transgression was associated with a very active tectonic phase including uplift of the Carpathians, orogeny-parallel and perpendicular extension and eastward subduction rollback stretching the Pannonian back-arc basin (Horváth, 1993; Mazzolki and Helman, 1994; Fodor et al., 1998; Horváth et al., 2006, 2015; Kováč et al., 2017b and references therein). In the south-west (Austria) this phase is referred to as 

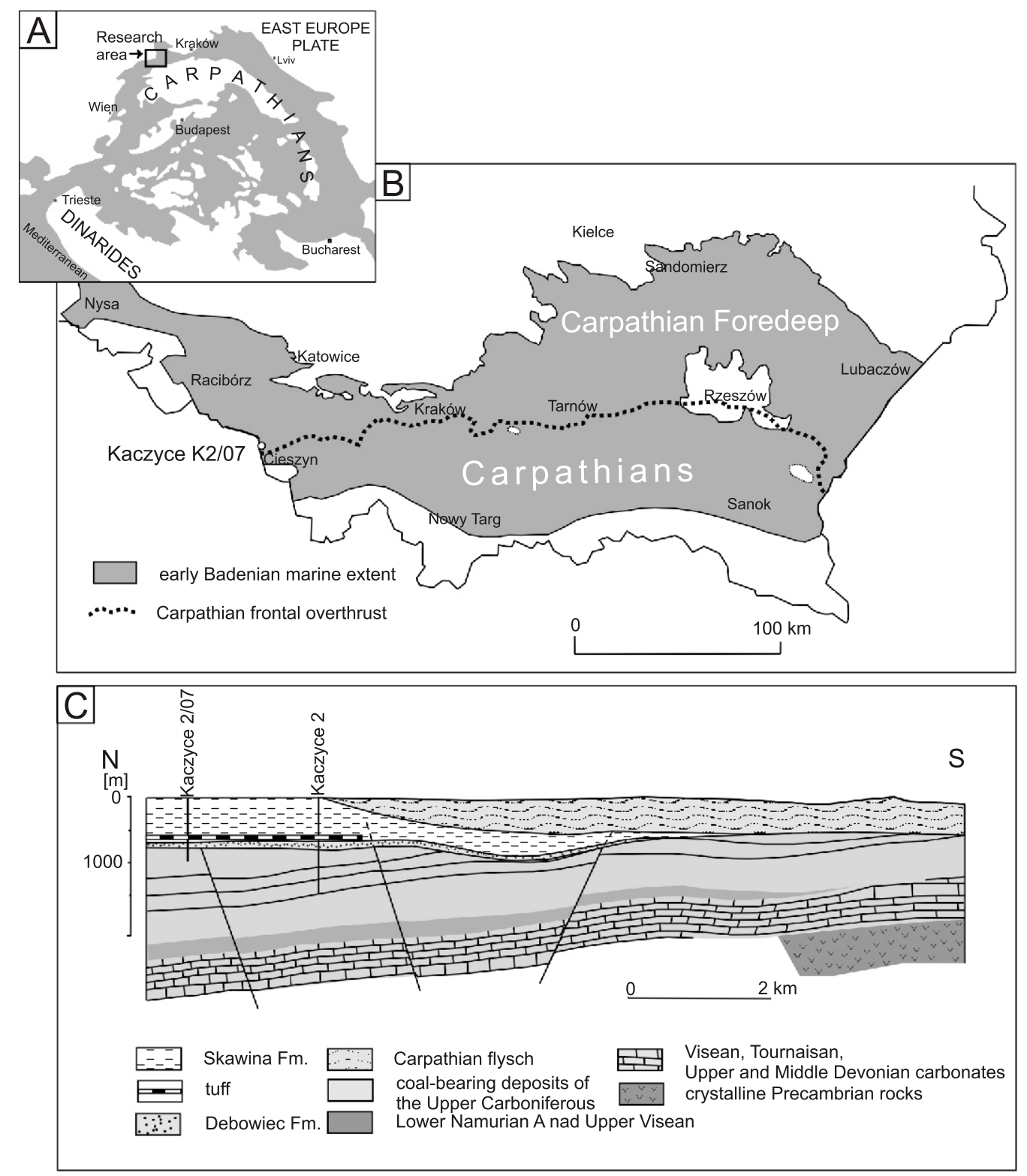

Fig. 1. Location of exploration borehole Kaczyce K2/07 in the geological setting of the Carpathian Foredeep

A - palaeogeographic reconstruction of the Central Paratethys (early Badenian; after Rögl, 1998); B extent of the early Badenian marine basin in the Polish Carpathian Foredeep (after Ney et al., 1974); C geological cross-section of the study area (after Bogacz et al., 1984)

the Styrian tectonic phase (Stille, 1924). The Neogene tectonic evolution of Carpatho-Pannonian region was accompanied by eruptions of various magmas (e.g., Szabó et al., 1992; Pécskay et al., 2006; Harangi and Lenkey, 2007). Very large explosive eruptions of silicic magmas occurred during the Early to Middle Miocene, coeval with the main lithospheric thinning and formation of the Pannonian Basin. This silicic volcanism appears to have produced one of the most voluminous volcanic deposits in Europe (volume estimate over $10 \mathrm{~km}^{3}$ ) during the Miocene (Lukács et al., 2015).

Various authors have suggested that the different steps of the Badenian transgression were assisted by eustatic changes (e.g., Oszczypko et al., 2006; Kováč et al., 2007; Hohenegger et al., 2014), such as the Mi2a and Mi3a sea level rises (Kominz et al., 2008; John et al., 2011) or TB 2.3 high stand (Haq et al., 1988). In the Polish Carpathian Foredeep, depocentres migrated northwards during the Badenian, and the sea covered the foreland plate and marginal parts of the Carpathians (Ney et al., 1974; Fig. 1). Profiles containing a full sequence of early Badenian deposits are relatively rare, and are mainly known from boreholes (e.g., Oszczypko and Oszczypko-Clowes, 2011). Sedimentation started generally with conglomerates (Dębowiec Formation; Buła and Jura, 1983). In the western part of the Foredeep these passed into an up to 1,000 m thick succession of claystones and mudstones with rare interbedded sandstones (Skawina Formation; Alexandrowicz et al., 1982). Towards the north and east, the thickness of those deposits markedly decreased to tens of metres or even to several metres. 
In this paper, we provide new results on samples taken from such a borehole (Kaczyce K2/07) located near the town of Cieszyn (Fig. 1C). We focus on reconstructing the chronology of the lower Badenian marine deposits at the beginning of the transgression in the Carpathian Foredeep (lower Skawina Fm.) using radio-isotopic dating $\left({ }^{40} \mathrm{Ar} /{ }^{39} \mathrm{Ar}\right)$ of a volcanic tuff horizon and the biostratigraphy of calcareous nannoplankton and foraminifera. The new age data will help to better understand the nature of the Badenian transgression in the northern part of the Central Paratethys.

\section{GEOLOGICAL SETTING}

The Polish Carpathian Foredeep can be subdivided into two parts: the inner (southern) and the outer (northern) basins (Ney et al., 1974). The inner foredeep, located beneath the Carpathian nappes, is $>50 \mathrm{~km}$ wide and is composed of Early to Middle Miocene autochthonous and allochthonous deposits. The width of the outer foredeep (outside the Carpathians) varies between $30-40 \mathrm{~km}$ in the western segment and reaches up to $90 \mathrm{~km}$ in the eastern part. The outer foredeep is filled with Middle Miocene marine deposits, ranging from a few hundred metres in thickness in the northern part to up to $3,000 \mathrm{~m}$ in the southeastern part.

The study area is located in the southwestern part of the outer Carpathian Foredeep in Poland (Fig. 1). In this area, the basement below the Miocene comprises Carboniferous deposits with sandstones, conglomerates, and shale with coal seams (Ruda Beds and Załęże Beds), belonging to the southern rim of the Upper Silesian Coal Basin. This basement is strongly morphologically differentiated, with erosional palaeovalleys, canyons, and ridges. The borehole examined is located on the eastern slope of the Ostrava-Karvina Ridge (e.g., Jachowicz and Jura, 1987; Picha et al., 2006), generally running in a east-west direction.

The Carboniferous rocks are overlain by younger deposits of the so-called Red Beds (e.g., Wagner, 1983; Dopita and Kumpera, 1993). They are Jurassic and Cretaceous residual deposits formed during weathering of Carboniferous rocks, as indicated by e.g., the red colour of the beds and the occurrence of erosional breccia in the roof of the Carboniferous rock formation. The thickness of the weathering-zone cover is variable and amounts is $>12 \mathrm{~m}$ in the study area.

Middle Miocene deposits lie directly on top of the weathering cover, and are represented by a 40-90 m thick succession of transgressive Dębowiec conglomerates and sandstones, containing Upper Carboniferous clasts. The spatial extent of the conglomerates and sandstones is related to the palaeo-morphology of the substrate (Buła and Jura, 1983). A characteristic feature of the conglomerates is the proportion of clastic material from the northern periphery of the basin, mainly of Carboniferous and Devonian rocks (Doktor, 1992, 1994). These deposits represent an alluvial fan system. The oldest occur in the southern part of the area, and the youngest in the north. The conglomerates reach upwards into the Skawina Formation. According to Oszczypko and Oszczypko-Clowes (2003), the Dębowiec conglomerates are of early Badenian-late Karpatian age (late Burdigalian-Langhian).

The Skawina Formation includes marine clayey sediments with a rich microfauna (Gonera, 1997, 2000; Gonera and Bukowski, 2012) and nannoplankton (e.g., Peryt, 1997) previously assigned to the "sub-evaporitic clays". Its stratotype was identified in the Borek Szlachecki borehole near Skawina (Alexandrowicz et al., 1982). Three main lithofacies were distinguished (Alexandrowicz, 1963a, 1997). Grey fossiliferous marly clays (Tegel facies), reaching up to $\sim 200 \mathrm{~m}$ in thickness, are most common; they occur in the central part of the basin. In the southern part of the basin, up to $650 \mathrm{~m}$ of grey clays (Schlier facies) occur, interbedded with silty and fine-grained sands. In the northern part of basin a shallow water marine facies was identified, characterized by the presence of shelly and organodetrital Lithothamnium limestone and marl intercalations, abundant in macro- and microfossils, within marly clays.

The foraminiferal assemblages described by Alexandrowicz (1963a) are locally used for the Badenian deposits (Table 1). The oldest foraminiferal assemblage recognized (IIA, IIB) appear in the lower part of the Skawina Formation. It is known as the Lanzendorf or the Cracow Assemblage (Alexandrowicz, 1957). In the lower part of the Skawina Fm., containing this rich and characteristic foraminiferal assemblage IIA or IIAB, a thick volcanic ash layer (tuffite; up to $2 \mathrm{~m}$ thick) was found. It has been described in many profiles (10 boreholes) in the western part of the Polish Carpathian Foredeep (Parachoniak, 1960, 1962; Alexandrowicz, 1963a, b, 1997; Alexandrowicz and Pawlikowski, 1978), and it is called the Chełmek Tuffite Bed (Alexandrowicz, 1997) or level tf-2 (see Bukowski et al., 2010: fig. 2).

The exploratory borehole, Kaczyce K2/07, is located within the range of the Schlier Facies and displays lower Badenian deposits. In the lower part of the Skawina Formation a layer of tuffite $(1.6 \mathrm{~m})$ occurs.

There are also older Lower Miocene deposits, belonging to the inner foredeep, located to the south-east and east of the study area. These deposits are called the sub-Dębowiec beds (Konior and Krach, 1965; Konior, 1981), the Zebrzydowice Formation (Buła and Jura, 1983), or Stryszawa and Sucha formations (Ślączka, 1977). There was no evidence of such deposits in the Kaczyce K2/07.

Central Paratethys foraminiferal zonation of the Badenian deposits in the western part of the Carpathian Foredeep

\begin{tabular}{|c|c|c|c|c|c|}
\hline \multicolumn{3}{|c|}{$\begin{array}{c}\text { Chronostratigraphy } \\
\text { Central Paratethys } \\
\text { (Papp et al., 1978; Rögl, 1996) }\end{array}$} & \multirow{2}{*}{$\begin{array}{c}\text { Planktonic foraminiferal zone } \\
\text { (Cicha et al., 1975) } \\
\text { Velapertina indigena }\end{array}$} & \multirow{2}{*}{$\begin{array}{c}\text { Benthic foraminiferal zone } \\
\text { (Papp et al., 1978; Rögl and } \\
\text { Stelninger, 1984; Steininger et al., } \\
\text { 1985) } \\
\text { Bulimina-Bolivina Zone }\end{array}$} & \multirow{2}{*}{$\begin{array}{c}\begin{array}{c}\text { Foraminiferal assem- } \\
\text { blage zone }\end{array} \\
\text { (Alexandrowicz, 1958, } \\
\text { 1963a) } \\
\text { IIIB }\end{array}$} \\
\hline \multirow{7}{*}{ 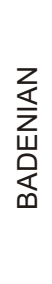 } & \multirow{5}{*}{ Late Badenian } & Kosovian & & & \\
\hline & & \multirow{4}{*}{ Wielician } & \multirow{4}{*}{$\begin{array}{l}\text { Globigerina druryi-Globigerina } \\
\text { decoraperta }\end{array}$} & \multirow{4}{*}{ Zone with agglutinated foramnifera } & IIIA \\
\hline & & & & & evaporites \\
\hline & & & & & IID \\
\hline & & & & & IIC \\
\hline & \multirow{2}{*}{ Early Badenian } & \multirow{2}{*}{ Moravian } & \multirow{2}{*}{$\begin{array}{c}\text { Orbulina suturalis/Praeorbulina } \\
\text { glomerosa }\end{array}$} & \multirow{2}{*}{ Lagenidae Zone } & IIB \\
\hline & & & & & IIA \\
\hline
\end{tabular}


LITHOSTRATIGRAPHY OF THE KACZYCE K2/07 BOREHOLE

The Kaczyce K2/07 borehole was drilled by the OKD Company in 2007 as an exploration borehole in search of coal in the Ostrava-Karvina coalfield in the western part of the mining area of the abandoned "Morcinek" Coal Mine. The borehole is located $\sim 2 \mathrm{~km}$ north of the frontal thrust of the Carpathians, in the vicinity of the Polish-Czech border, and $\sim 10 \mathrm{~km}$ north of Cieszyn (Fig. 1). The borehole is $1,000 \mathrm{~m}$ deep. Full cores are available only for the section $600-1,000 \mathrm{~m}$ (Fig. 2).

The Kaczyce K2/07 borehole cuts through 30 m of Quaternary deposits (loams, clays and gravels) and then through the autochthonous Miocene foredeep deposits of the Skawina Formation (30-684 m), represented by a succession of grey and greenish marly clays with intercalations of sands and sandstones (Fig. 2). The proportion of sandy material in the succession decreases in the lower part of the profile (from $632 \mathrm{~m}$ depth). A thick layer of white and pale grey tuffite was found in the depth interval 648.5-650.1 m. The Miocene deposits of the Skawina Formation are unfolded and lie almost horizontally.

From 684 to $728 \mathrm{~m}$ depth, pale grey, coarse-grained sandstones and conglomerates are present (Fig. 3C). The sandstones are fragile, crumbling, and porous. They contain quartz grains and numerous fragments of Carboniferous rocks: sandstones, dark slates and clasts of coal (reaching up to $50 \mathrm{~mm}$, or $15 \mathrm{~mm}$ on average), originating from the Westphalian $A B$ mudstone succession (Jachowicz and Jura, 1987).

In the interval 728-744.3 $\mathrm{m}$, there are coarse, polymictic conglomerates with numerous boulders $(5-20 \mathrm{~cm}$ across) of grey-green sandstone, reddish and cream coloured metamorphic rocks, and black slate (Fig. 3B). Based on lithology, the entire unit of pale grey sandstones and polymictic conglomerates $(684-744.3 \mathrm{~m})$ can be included in the Dębowiec Formation (Tołwiński, 1950; Kuciński et al., 1975; Garecka et al., 1996). This formation lies unconformably (at depth $744 \mathrm{~m}$ ) on deposits of the weathering zone of the Carboniferous substrate (Red Beds), in the form of greenish conglomerates, with a characteristic red binder.

In the depth range $745-751 \mathrm{~m}$, the green conglomerate gradually turns into a rusty red conglomerate (Fig. 3A). Within that weathering zone, very large white blocks of sandstone (up to $80 \mathrm{~cm}$ in size) are found at the depth intervals 751-753 and $760.1-762 \mathrm{~m}$. Below the weathering zone there are typical Carboniferous deposits formed by the Mudstone series (Załęże Beds, 762-794 m) and the Upper Silesian Sandstone series (Ruda Beds, 794-1,000 m).

\section{TUFFITE}

A thick layer of pyroclastic material occurs within marly clays in the depth interval 648.5-650.1 m (Fig. 3). It includes laminated white tuff and tuffite with a total thickness of $160 \mathrm{~cm}$. Macroscopically, the white and pale grey volcanic ash layer has horizontal lamination and is graded. The interval does not contain carbonates (as tested with $\mathrm{HCl}$ ).

Binocular observations showed that the tuff interval contains some fining upward layers: fine-grained at the top and medium to coarse-grained (sand-size) at the bottom. At the bottom (649.5-650.1), the proportion of terrigenous (siliciclastic) material is minimal. These deposits could be referred to as crystal tuff according to the definition of Pettijohn (1949). Some flakes of biotite, quartz grains and glass shards are visible to the naked eye.

Higher in the interval (648.5-649.5), the admixture of the non-pyroclastic material rises, and these rocks could be described as tuffites (Parachoniak, 1962). Their relatively large
Kaczyce K2/07

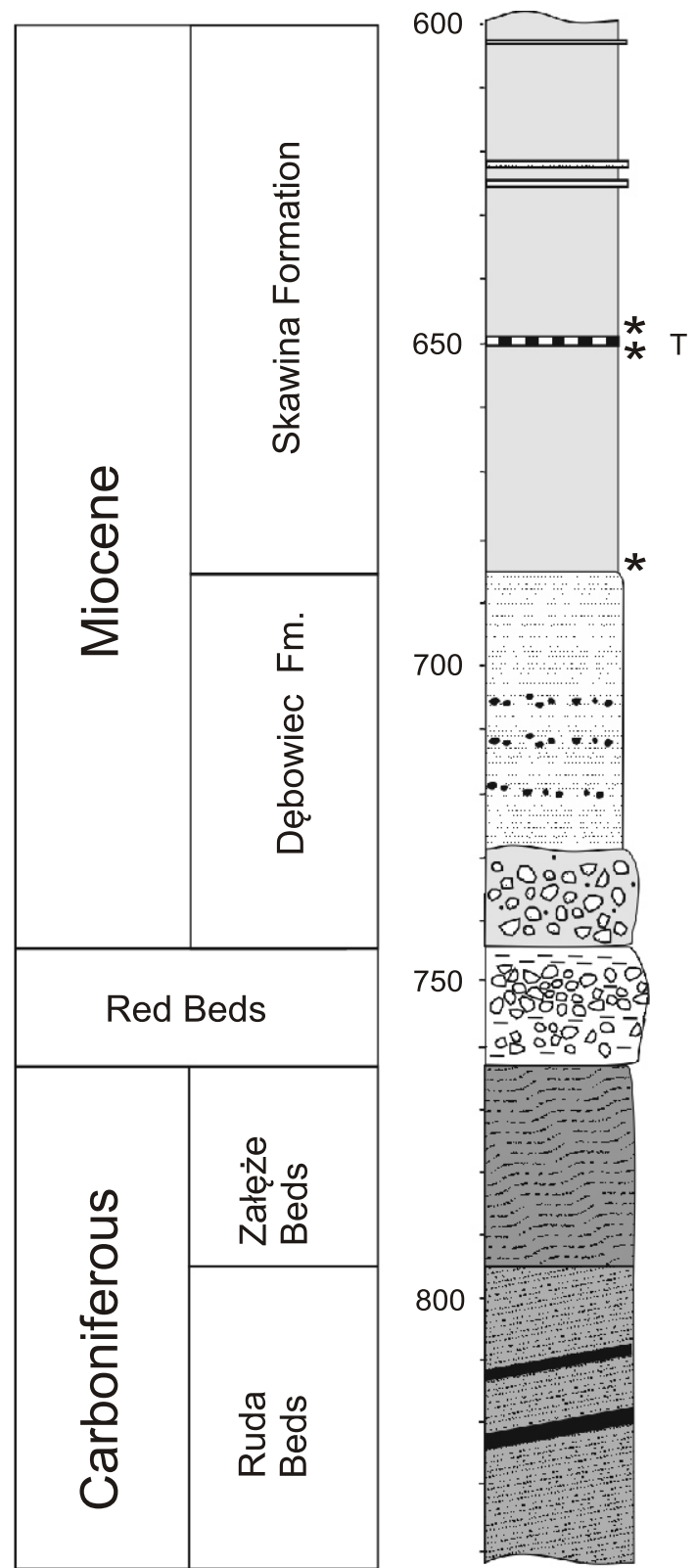

clays, with intercalation of sands

coarse-grained sandstones

polymictic conglomerates

green and rusty red conglomerates

mudstones

sandstones with layers of coal

* $\quad$ samples for microfauna

T tuffite

Fig. 2. Lithostratigraphic profile of the Kaczyce K2/07 borehole 

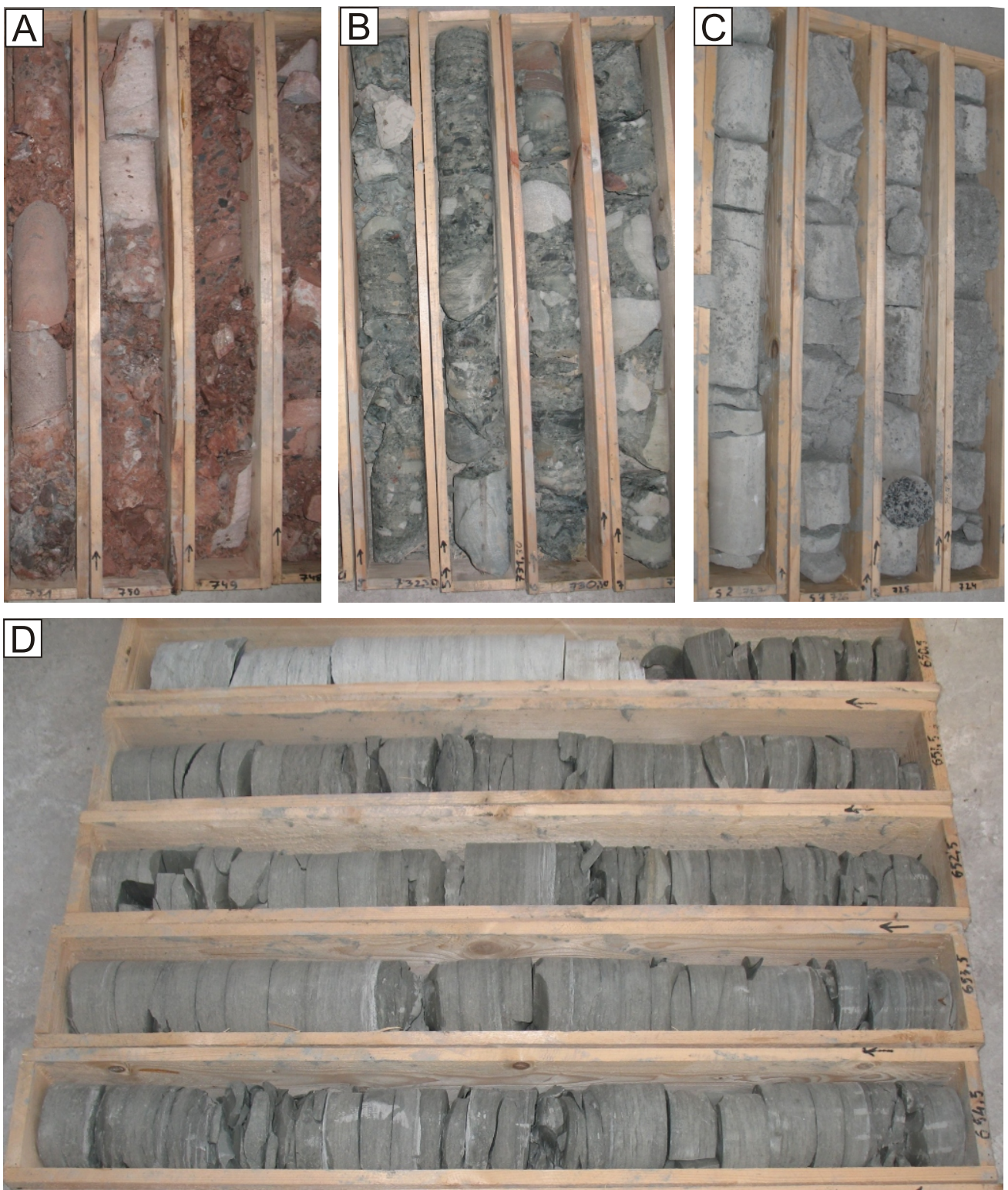

Fig. 3. Core Kaczyce K2/07 shows Middle Miocene deposits lie directly on top of the weathering cover of Carboniferous rocks (photo J. Misiak)

A - Red Beds, deposits of the weathering zone of the Carboniferous substrate, in the form of conglomerates, with a characteristic red binder; $\mathbf{B}$ - polymictic conglomerates with numerous boulders of grey-green sandstone and reddish and cream coloured metamorphic rocks; $\mathbf{C}$ - coarse-grained porous sandstones and conglomerates containing quartz grains and numerous fragments of Carboniferous rocks and clasts of coal; D - layer of tuffite (white interval on top of picture) within grey and greenish marly clays (Skawina Fm.) from the borehole studied, Kaczyce K2/07

thickness and stratigraphic position in the lower part of the Skawina Formation suggests that the horizon extends regionally. It was previously recognized in other boreholes and exposures in the Carpathian Foredeep (e.g., Parachoniak, 1962; Alexandrowicz, 1997; Bukowski, 2011).

\section{MATERIAL AND METHODS}

Two tuffite samples were taken from the Kaczyce K2/07 core; one fine-grained, laminated, and slightly bentonized (sample K2/3) from a depth of $648.8 \mathrm{~m}$, and one coarse-grained tuff with finely excellently preserved pyroclastic minerals from a depth of $650.1 \mathrm{~m}$ (sample K2/4).

Chemical analyses of volcanic glass, plagioclases and K-feldspars, by SEM/EDS microprobe, was performed on both samples (K2/3 and K2/4). SEM/EDS analyses were conducted in the FESEM Laboratory of the Institute of Geological Sciences, Jagiellonian University using a NORAN Vantage spectrometer coupled with a HITACHI S-4700 scanning electron microscope operated at $15 \mathrm{kV}$.

Minerals from K2/4 were extracted for ${ }^{40} \mathrm{Ar} /{ }^{39} \mathrm{Ar}$ dating by using standard mineral separation procedures. The heavy mineral concentrate was first separated into a heavy $\left(>2.62 \mathrm{~g} / \mathrm{cm}^{3}\right)$, 
median $\left(2.62-2.4 \mathrm{~g} / \mathrm{cm}^{3}\right)$ and light fraction $\left(<2.4 \mathrm{~g} / \mathrm{cm}^{3}\right)$ by use of different tetrabromoethane $\left(\mathrm{C}_{2} \mathrm{H}_{2} \mathrm{Br}_{4}, \mathrm{~d}=2.97 \mathrm{~g} / \mathrm{cm}^{3}\right)$ solutions at the Faculty of Geology, Geophysics and Environmental Protection, AGH University of Science and Technology in Kraków. At this stage, preliminary analysis on sanidine crystals in the median mineral fraction was performed by the Raman method.

\section{${ }^{40} \mathrm{Ar}{ }^{39} \mathrm{Ar}$ DATING}

The material of sample K2/4 was further processed at the Mineral Separation facility of the Faculty of Earth and Life Sciences of VU University Amsterdam in order to separate biotite and sanidine minerals for ${ }^{40} \mathrm{Ar}{ }^{139} \mathrm{Ar}$ dating. It was labelled as sample KAC. Sanidine grains were separated from the $2.54-2.59 \mathrm{~g} / \mathrm{cm}^{3}$ density fraction (using di-iodomethane). The material was then cleaned in an ultrasonic water bath and dry sieved into the fractions $250-400 \mu \mathrm{m}$ and $400-500 \mu \mathrm{m}$. Both were further purified by magnetic separation over a Frantz isodynamic separator, and subsequently cleaned by a $15 \mathrm{~min}$ ute ultrasonic $\mathrm{HNO}_{3}$ bath, and a 10 minute diluted $\mathrm{HF}$ bath. A final selection step involved hand-picking of the size fractions 250-400 $\mu \mathrm{m}$ and 400-500 $\mu \mathrm{m}$ under an optical microscope. Only transparent sanidine grains were selected.

Biotite grains were separated from the density fraction $>3.0 \mathrm{~g} / \mathrm{cm}^{3}$. After an additional cleaning step in an ultrasonic water bath, the remainder was dry sieved into two size groups: $<90-200 \mu \mathrm{m}$ and 200-500 $\mu \mathrm{m}$. During the final hand-picking step the thickest, most angular hexagonal biotite minerals without visible inclusions under an optical microscope were selected for radio-isotopic dating from the size fraction $>200 \mu \mathrm{m}$.

Mineral separates were packed in a $6 \mathrm{~mm}$ ID Al vial together with Fish Canyon Tuff sanidine (FCs) standards. Samples and standards were irradiated at the Oregon State University TRIGA reactor in the cadmium shielded CLICIT facility for 18 hours in two irradiations (VU107 for sanidine and VU109 for biotite). After irradiation samples and standards were unpacked and loaded in a 185 hole Cu tray and baked overnight at $250^{\circ} \mathrm{C}$ under vacuum. This tray was then placed in a doubly pumped vacuum chamber with $\mathrm{Zn}-\mathrm{S}$ window and baked overnight at $120^{\circ} \mathrm{C}$ under high vacuum. This chamber was connected to a ThermoFisherNGPrep gas purification line that originally was equipped with four SAES-NP10 getters, a cold finger, an ion gauge, two inlets and two pipette systems. Samples were heated using a $25 \mathrm{~W}$ Synrad $\mathrm{CO}_{2}$ laser. Sample gas was exposed to three of the NP10 getters (two hot and one cold) during 3 min and let into the an ARGUS VI+ noble gas mass spectrometer for analyses.

${ }^{40} \mathrm{Ar} /{ }^{39} \mathrm{Ar}$ analyses were carried out at the geochronology laboratory of the VU University on a ARGUS VI+ noble gas mass spectrometer, which is a high sensitivity, low resolution multi-collector noble gas mass spectrometer with an internal volume of $710 \mathrm{ml}$. The mass spectrometer is equipped with four Faraday cups at the $\mathrm{H} 2, \mathrm{H} 1, \mathrm{AX}$ and L1 positions and two compact discrete dynodes (CDDs) at positions L2 and L3. The system is equipped with a $10^{12} \mathrm{Ohm}$ amplifier on $\mathrm{H} 2$ and $10^{13} \mathrm{Ohm}$ amplifiers on $\mathrm{H} 1, A X$ and $\mathrm{L} 1$ cups. The resolution of the system is $\sim 200$ and therefore does not resolve hydrocarbon or chlorine interferences. The ARGUS VI+ has a NP10 getter and ion gauge on the source of the mass spectrometer. The NP10 getter is run cold and the ion gauge is turned off during analyses, because of its pumping capacity for argon. Samples were run on the H2-L2 collectors (m/e40 on H2, m/e39 on H1, m/e38 on AX, m/e37 on L1 and m/e 36 on L2). Bias between the different detectors was monitored by (1) measurement of ${ }^{40} \mathrm{Ar}$ air pipettes across the different Faraday cups; (2) measurement of
${ }^{40} \mathrm{Ar}$ blanks on all detectors and ( 3 ) by measurement of mass 44 $\mathrm{CO}_{2}$ in dynamic mode on all detectors. Systematic bias of up to $14 \%$ between the detectors was found, but this was reproducible over periods of weeks. As with Phillips and Matchan (2013) we did not apply bias corrections, but analysed samples and standards in the same tray (and thus at more or less the same time) alternating with air pipettes of different intensities in the same range as the samples and standards. Line blanks were measured every 2-3 unknowns and were subtracted from succeeding sample data.

Single grain fusions were performed on 25 biotite and 15 sanidine samples (only size fraction 400-500 $\mu \mathrm{m}$ ). Data reduction was done in ArArCalc (Koppers, 2002). Ages were calculated with Min et al. (2000) decay constants and $28.201 \pm$ 0.022 My for FCs (Kuiper et al., 2008). The atmospheric air value of 298.56 from Lee et al. (2006) was used. The correction factors for neutron interference reactions are $(2.64 \pm 0.02) \times$ $10^{-4}$ for $\left({ }^{36} \mathrm{Ar} /{ }^{37} \mathrm{Ar}\right)_{\mathrm{Ca}},(6.73 \pm 0.04) \times 10^{-4}$ for $\left({ }^{39} \mathrm{Ar} /{ }^{37} \mathrm{Ar}\right)_{\mathrm{Ca}},(1.21$ $\pm 0.003) \times 10^{-2}$ for $\left({ }^{38} \mathrm{Ar} /{ }^{39} \mathrm{Ar}\right)_{\mathrm{K}}$ and $(8.6 \pm 0.7) \times 10^{-4}$ for $\left({ }^{40} \mathrm{Ar} /{ }^{39} \mathrm{Ar}\right)_{\mathrm{K}}$. All errors are quoted at the $2 \sigma$ level and include all analytical errors. All relevant analytical data for age calculations can be found in the online supplementary material.

\section{BIOSTRATIGRAPHY}

Four samples extracted from the depths 684.0, 650.2, 648.8 and $648.5 \mathrm{~m}$ were used in the micropalaeontological analysis of calcareous nannoplankton. The rock samples were used to prepare smear slides by the standard method described by Báldi-Beke (1984) to carry out microscopic observations. For the purpose of light microscope examination, a fine water suspension of each sample was spread on a glass slide. A drop of the suspension was placed on the slide after stirring and a short period of settling. Once the drop had dried, the slide was covered with Canada balsam and covered with glass. The smear slides were inspected with a Nikon Eclipse LV100POL light microscope at 1,000× magnification. Biostratigraphic determinations followed the nannoplankton levels of Martini (1971), Martini and Müller (1986), Young (1998) and Švábenická (2002).

Foraminifers were studied in 4 core samples collected from the depths $684.0,650.2,648.8$ and $648.5 \mathrm{~m}$. The rock samples were fairly small in volume: $684.0 \mathrm{~m}: 250 \mathrm{~g}, 650.2 \mathrm{~m}: 350 \mathrm{~g}$, $648.8 \mathrm{~m}: 209 \mathrm{~g}, 648.5 \mathrm{~m}: 450$ respectively. All samples were subjected to standard maceration and levigation methods $\left(\mathrm{Na}_{2} \mathrm{SO}_{4}\right.$, sieve: $\left.0.063 \mathrm{~mm}\right)$. Owing to inadequate results additional processes using liquid nitrogen were applied to the samples collected from 648.5 and $648.8 \mathrm{~m}$. Species identification was conducted by use of a HUND-TECH Micro SST microscope with foraminifer taxonomy generally according to Cicha et al. (1998). Photographs of the selected foraminifera were taken without specimen spraying, using a FEI environmental scanning electron microscope (ESEM), model QUANTA 200FEG, at the Laboratory of the Faculty Geology, Geophysics and Environmental Protection, AGH University of Science and Technology in Kraków.

\section{RESULTS}

\section{PETROGRAPHIC STUDY}

The tuffite represents typical vitroclastic and vitrophyric texture and parallel-laminated, fine- to coarse-grained structures (pyroclasts $<2 \mathrm{~mm}$ across). Volcanic glass shards and smaller proportions of biotite, plagioclase, sanidine, and pyroclastic 
quartz crystals dominate. Occasionally, heavy minerals such as zircon, allanite (a mineral of the epidote group), and apatite occur. In thin section, the glass shards are relatively thick with sharp edges. Platy and cuspate bubble-wall types of shards are colourless and isotropic. They vary in size from 0.05 to $0.2 \mathrm{~mm}$ across (Fig. 4). They are usually well-preserved and show some traces of devitrification in the outer parts of the grains only (Figs. 4 and 5).

The SEM/EDS analysis showed that the $\mathrm{SiO}_{2}$ content of the glass is relatively stable: $76.3-79.0 \%$. Similarly, the $\mathrm{Al}_{2} \mathrm{O}_{3}$ content shows no significant differences (12.0-14.3\%). The contents of $\mathrm{K}_{2} \mathrm{O}, \mathrm{Na}_{2} \mathrm{O}, \mathrm{CaO}$, and $\mathrm{Fe}_{2} \mathrm{O}_{3}$ display slight fluctuations, within generally constant ranges (Appendix $1^{*}$ ). Interestingly, the barium content is relatively high $(0.8-2.2 \%)$ in the volcanic glass. These results indicate that the chemical composition of the volcanic glass is typical of ash of rhyolitic origin.

Euhedral crystals of biotite, in the form of black hexagonal tablets and blocks, are arranged unidirectionally and emphasise the layered rock texture. Some biotite plates are bent or broken (Figs. 4 and 5), but most are undamaged and reach up to $1 \mathrm{~mm}$ across. Quartz grains are angular with sharp edges. They exhibit distinct traces of magmatic corrosion (Fig. 5A, D) indicating their volcanic origin (pyroclastic quartz, Alexandrowicz, 1957). The quartz grain diameter reaches $2 \mathrm{~mm}$.

Plagioclase feldspar grains ( $\left.\sim \mathrm{An}_{20-30}\right)$ occur commonly and are usually non-weathered and rarely cracked. They include abundant polysynthetic (albite law) or multiple twinning. The SEM/EDS analyses showed that most of the plagioclases are andesine and oligoclase, with various chemical compositions observed in single crystals. Sanidine crystals (up to $1 \mathrm{~mm}$ across) occur less frequently; usually twinning was visible, in accordance with the Carlsbad law (Figs. 4C and 5E).

Magnetite and pyrite, being opaque minerals, occur rarely in the samples. Individual, large crystals of allanite $(2 \mathrm{~mm})$ with small inclusions of monazite and zircon (Fig. 5G) were identified by the SEM/EDS method.

The tuffite matrix consists mainly of fine-grained glass and its transformation products, and clay minerals. The coarse-grained tuffite is grain-supported with sparse matrix. The fine-grained tuffite is dominantly matrix-supported. The proportion of clay minerals increases gradually between the two types (Fig. 5).

\section{RADIO-ISOTOPE DATING}

For the sanidine mineral analyses, all ${ }^{40} \mathrm{Ar} /{ }^{39} \mathrm{Ar}$ measurements with a high percentage of radiogenic ${ }^{40} \mathrm{Ar}^{*}(>85 \%)$ and a $\mathrm{K} / \mathrm{Ca}>5$ are considered reliable. This is valid for 9 out of 15 single grain measurements of the Kaczyce- 2 tuff. Their complete age range is $14.22 \pm 0.02$ and $14.31 \pm 0.01 \mathrm{Ma}$. Three groups with mean ages of $14.22(n=1), 14.26-14.27 \mathrm{Ma}(\mathrm{n}=3)$ and 14.29-14.31 Ma $(n=5)$, respectively, are distinguished. Due to the volcanoclastic nature of the tuff, reworked, detrital grains might be present in the sample. These components are older than the eruption age, so the oldest group likely does not represent the eruption age. Following this reasoning, the youngest reliable result with an age of $14.22 \pm 0.01 \mathrm{Ma}$ is the best estimate of the eruption age. Alternatively, we could assume that some ${ }^{40} \mathrm{Ar}$ loss occurred, and that the eruption age is approximated best by a statistically sound mean value (data points are included until MSWD > T-test statistic using a $2 \sigma$ confidence limit). This approach is similar to U/Pb studies where the youngest grain(s) might represent $\mathrm{Pb}$ loss and the oldest grain(s) xenocrystic components (see e.g., Sahy et al., 2015). In this case the tuff has an age of $14.27 \pm 0.03 \mathrm{Ma}$ including all errors using the approach of Kuiper et al. (2008).

For the biotite separate, the percentage of ${ }^{40} \mathrm{Ar}^{*}$ of the 25 measured ranges from $\sim 30-99 \%$ where the lower radiogenic ${ }^{40} \mathrm{Ar}$ yields suggest some degree of alteration. The ${ }^{40} \mathrm{Ar}$ intensities range from 18-196 fA and with blank values of 10fA this is close to the detection limits of the system (Appendix 2). Analytical uncertainties are therefore relatively large for these biotite grains and single crystal analyses do not yield results that can be used for high-resolution age determination. Nevertheless, the age range of the six youngest grains overlaps with the statistically sound mean age value determined from ${ }^{40} \mathrm{Ar} /{ }^{39} \mathrm{Ar}$ dating on sanidine grains from the same sample (Fig. 6).

\section{MICROPALAEONTOLOGICAL STUDY}

Calcareous nannoplankton. In the sample collected of the bottom part of the Skawina layers $(684 \mathrm{~m})$, directly above the Dębowiec conglomerate level, numerous but poorly preserved calcareous nannoplankton assemblages with Coccolithus pelagicus (Wallich) Schiller, Helicosphaera carteri (Wallich) Kamptner, Reticulofenestra pseudoumbilica (Gartner) Gartner, and small Reticulofenestra species occurred. Less frequent were Pontosphaera multipora (Kamptner) Roth, Umbilicosphaera rotula (Kamptner) Varol, Helicosphaera waltrans Theodoridis, and $H$. aff. walbersdorfensis Müller, Cyclicargolithus floridanus (Roth et Hay) Bukry, Cy. abisectus (Müller) Wise, Calcidiscus premacintyrei Theodoridis, Umbilicosphaera jafarii Müller, Coccolithus miopelagicus Bukry, Sphenolithus heteromorphus Deflandre, C. macintyrei (Bukry et Bramlette) Loeblich et Tappan, $\mathrm{H}$. sellii (Bukry et Bramlette) Jafar et Martini, and Braarudosphaera bigelowii (Gran et Braarud) Deflandre appeared as individuals.

In a shallower sample $(650.2 \mathrm{~m})$, a sparse Miocene nannoplankton assemblage including $H$. carteri, $C$. pelagicus, R. pseudoumbilica, small-sized Reticulofenstra species, and single specimens of $C y$. floridanus, $U$. rotula, $U$. jafarii, $C$. miopelagicus, $P$. multipora, $H$. walbersdorfensis, $\mathrm{Cd}$. premacintyrei, S. heteromorphus, Holodiscolithus macroporus (Deflandre) Roth, and S. abies Deflandre was indentified.

An even more taxonomically impoverished nannoplankton association was found in the sample collected from the greenish silts at a depth of $648.5 \mathrm{~m}$. The sample contains mainly numerous fragments of placoliths, among others Reticulofenestra and $C$. pelagicus dominated. Single occurrences of poorly preserved $H$. carteri, U. jafarii, $H$. waltrans, Cy. floridanus, and Discoaster sp. were observed. The edges and surfaces of the coccoliths' plates bear traces of dissolution and corrosion.

No calcareous nannoplankton were found in the sample collected from the thin mudstone layer from $648.8 \mathrm{~m}$ depth. Redeposited species from the Eocene, Eocene-Oligocene, and Cretaceous were identified in the samples examined.

Foraminifera. The lowermost rock sample from the Skawina Formation (684 m) consists of a foraminiferal assemblage with a variable preservation and recrystallization grade. Many specimens could not be determined. The determinable assemblage is characterized by a mass occurrence of planktonic species (Fig. 8) represented mainly by Globorotalia bykovae Pishvanova, Globigerinita glutinata (Aisenstat), Globigerina tarchanensis Subbotina et Chutzieva, G. bulloides d'Orbigny, G. praebulloides Blow, Paragloborotalia cf. pseudopachyderma (Cita, Premoli Silva et Rossi), 

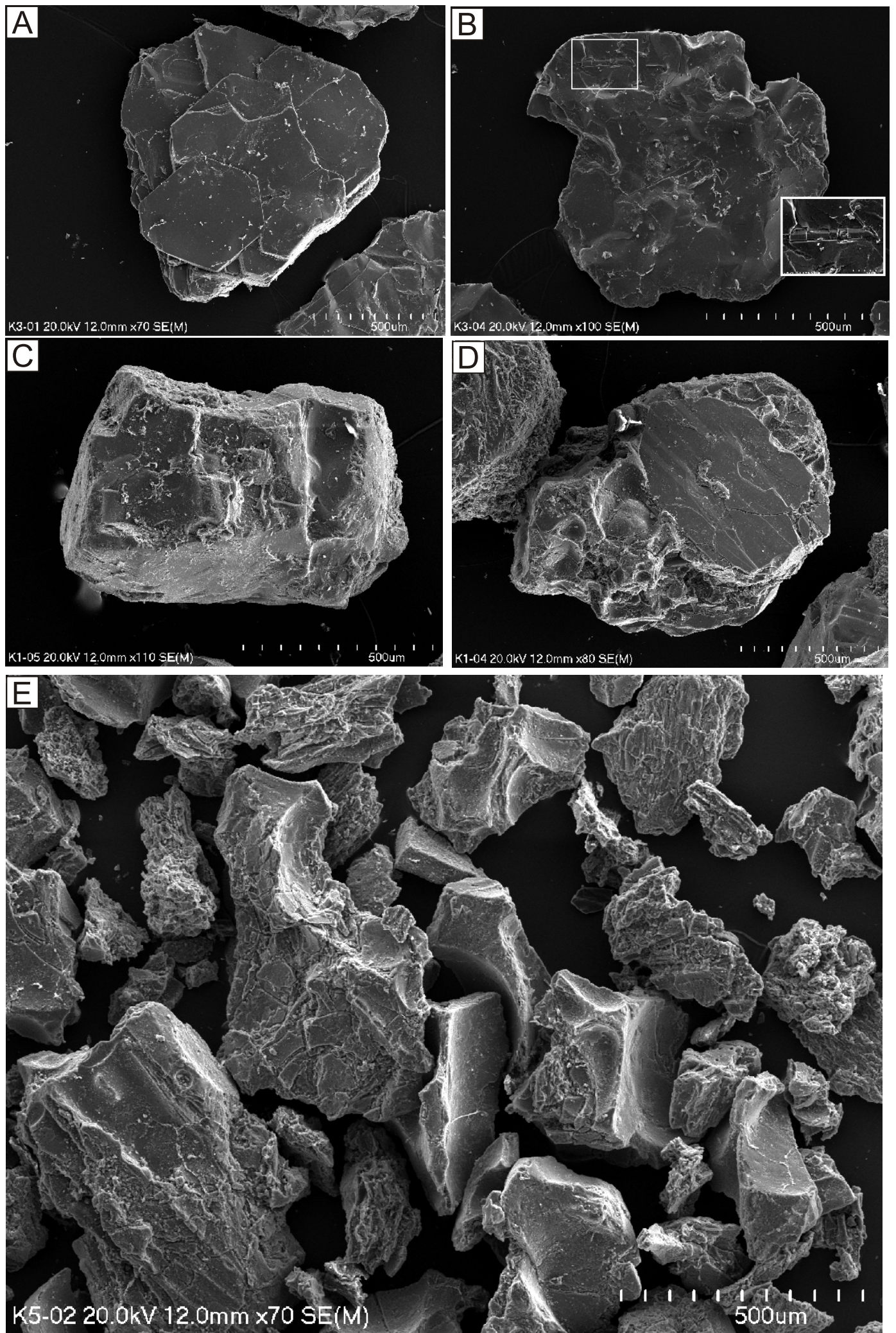

Fig. 4. SEM images of separated grains of pyroclasts

A - euhedral crystals of biotite, in the form of hexagonal tablets; $\mathbf{B}$ - biotite plate with an ingrown crystal of apatite; C - twinned sanidine crystal; D - plagioclase crystal within volcanic glass; $\mathbf{E}$ - separated grains of volcanic glass; sample K2/4, depth 450.1 m, Kaczyce K2/07 

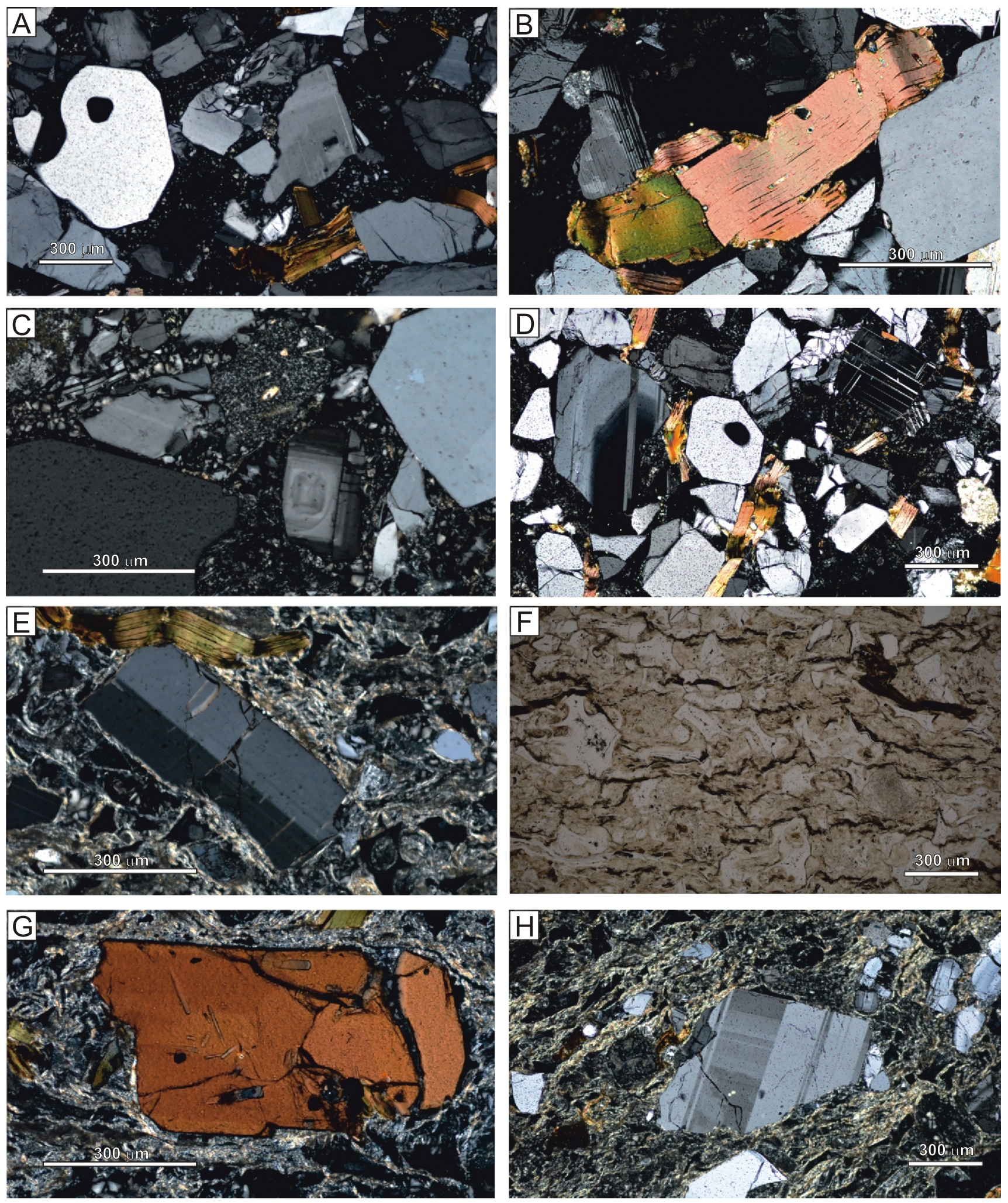

Fig. 5. Light microscope images of the coarse-grained tuff, sample K2/4, depth $450.1 \mathrm{~m}$, Kaczyce K2/07

A - large grain of embayed pyroclastic quartz with traces of magmatic corrosion, plagioclase and biotite, crossed polarized light (XPL); B biotite plate (in the centre of photograph), XPL; C - oscillatory zoned plagioclase grain (in the centre) between two large quartz grains, XPL; D - coarse-grained tuff composed of broken grains of plagioclase with polysynthetic twinning, pyroclastic quartz and single grains of carbonates, XPL; E - large sanidine crystal, simple twinned, in a groundmass of material resulting from devitrification of volcanic glass, XPL; F - volcanic glass shards, pumice type and the obsidian "Y" shape, ordinary light; $\mathbf{G}$ - large, broken allanite grain with fine inclusions of monazite and zircon, XPL; H - plagioclase grain (centre of photograph) with well-developed twinning, XPL 
Globigerinella obesa (Bolli), Globigerinoides bisphericus Todd, Gl. trilobus (Reuss), Orbulina suturalis Bronnimann, Praeorbulina glomerosa glomerosa (Blow), P. transistoria (Blow). Globorotalia bykovae dominate. The microfossil assemblage examined also includes fragments of sea-urchin spines.

Benthic foraminifera are rare and are mainly represented by: Melonis pompilioides (Fichtel et Moll), Angulogerina esuriens Hornibrook, Bulimina inflata Sequenza and single specimens of Cibicidoides conspiciendus Pishvanova (Fig. 7). Sporadic agglutinated foraminifers also occur but they most probably were redeposited from the Carpatian flysch deposits.

The second sample is located below the tuffites $(650.2 \mathrm{~m})$ and yielded numerous foraminifers both in a good preservation state and in a deformed recrystallized or pyritised form (Fig. 7). Benthic foraminifers are dominated by Nonionella turgida (Williamson) and Virgulinella pertusa (Reuss), and accompanied by Chilostomella ovoidea Reuss, Allomorphina trigona Reuss and Globocassidulina subglobosa (Brady). Planktonic foraminifers are dominated by small species: Globigerinita glutinata and G. tarchanensis, accompanied by single specimens of Globigerinella obesa, Globigerinoides trilobus, and Globorotalia bykovae (Appendix 3).

The third $(648.8 \mathrm{~m})$ and fourth $(648.5 \mathrm{~m})$ samples are practically devoid of microfossils and are represented only by deformed foraminifers and sponge spicules.

\section{DISCUSSION}

\section{BIOSTRATIGRAPHY AND ENVIRONMENT}

Calcareous nannoplankton. The samples from the depths $684.0,650.2$ and $648.5 \mathrm{~m}$, were assigned to the NN5 Zone based on the presence of $H$. carteri, C. pelagicus, $R$. pseudoumbilica, and small Reticulofenestra species. Helicosphaera ampliaperta Bramlette et Wilcoxon, the last occurrence (LO) of which defined the boundary between zones NN4 and NN5, was absent in the samples analysed. The stratigraphically important species for the NN5 Zone, S. heteromorphus, was represented as individuals at the depths of 684.0 and $650.0 \mathrm{~m}$.

The diagnostic species for Lower Badenian strata of the Central Paratethys, $H$. waltrans, occurred in the samples from 684.0 and 648.5 m depth (i.e. Švábenická, 2002; Rögl et al., 2006; Tomanova-Petrová and Švábenická, 2007; Melinte-Dobrinescu and Stoica, 2014). In the local nannoplankton zonation of the western Central Paratethys according to Bartol (2008), the first occurrence (FO) of $H$. waltrans defined the interval MuN5a that correlates with the lowermost part of NN5 in the standard zonation of Martini (1971). The LO of this species marks also the upper limit of the MuN5c interval which can be correlated with the MNN5b biozone of Di Stefano et al (2008) and with the upper boundary of the Helicosphaera waltrans Subzone in Theodoridis' zonation (1984) in the Mediterranean region. In the Eastern Paratethys $H$. waltrans was recorded in a short interval within the NN5 Zone (Tarkhanian Stage, lower Badenian) with $H$. carteri, $H$. intermedia Martini and S. heteromorphus (Andreyeva-Grigorovich and Savitskaya, 2000; Grigorovich, 2001). According to Švábenicka (2000), Ćorić and Rögl (2004), Ćorić et al. (2007) and Hohenegger et al. (2009), the FO of $\mathrm{H}$. waltrans is diachronous in the eastern and western part of the Central Paratethys, as well as in the Mediterranean region (Fornaciari et al., 1996; Di Stefano et al., 2008). Fornaciari (in: Fornaciari et al., 1996) correlated the range of $H$. waltrans with the upper part of the MNN5a and lower part of the MNN5b Subzones whereas Di Stefano et al. (2008) and Švábenicka (2002) mentioned that the ranges of $H$. waltrans and $H$. ampliaperta overlap. According to Theodoridis (1984) the common occurrence of this form was

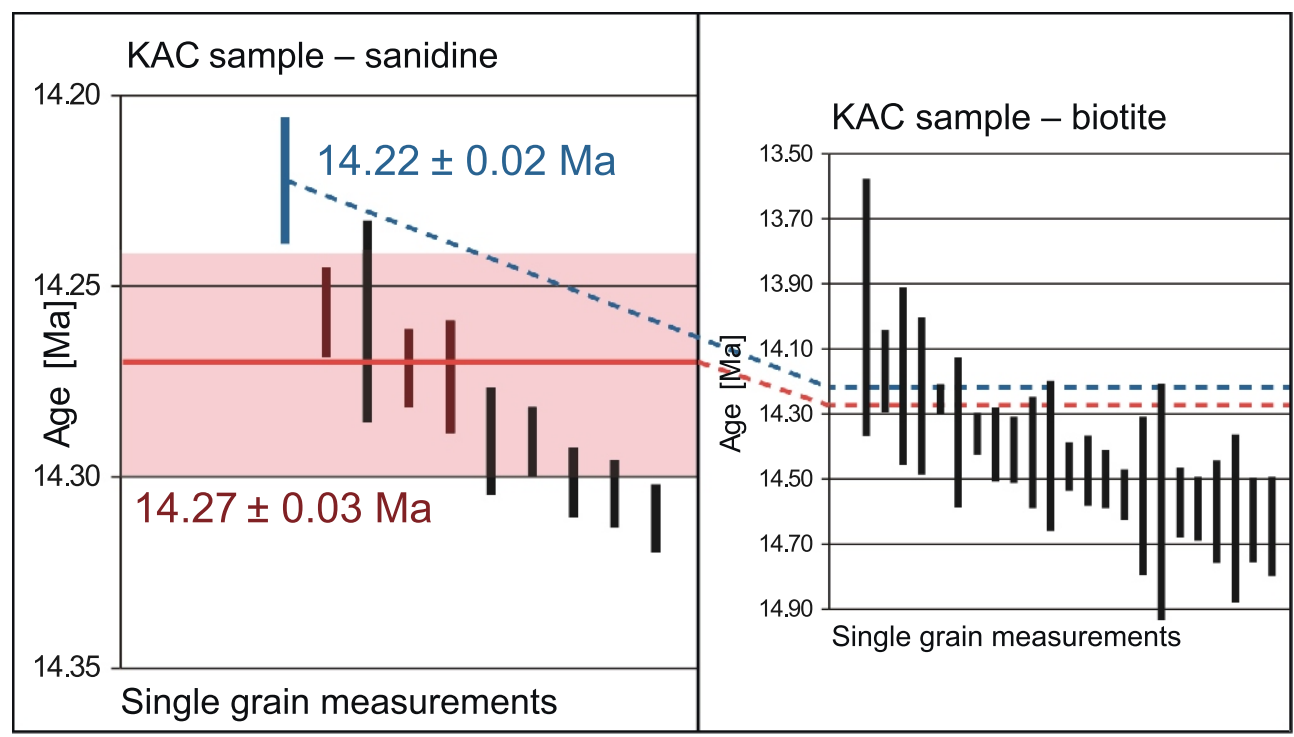

Fig. 6. Summary of ${ }^{40} \mathrm{Ar} /{ }^{39} \mathrm{Ar}$ results of sanidine and biotite minerals of sample KAC (core sample K2/4)

Individual ages are shown in ranked order with $2 \sigma$ analytical error bars. The three red vertical bars mark the sanidine samples used to calculate the weighted mean age that is marked by the red horizontal bar. The pink shaded area indicates the uncertainty limits following Kuiper et al. (2008). The blue vertical bar indicates the sanidine grain with the youngest age. The youngest generation biotite grains overlap with the ages derived from the sanidines 
A

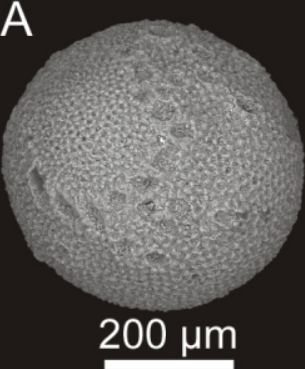

E
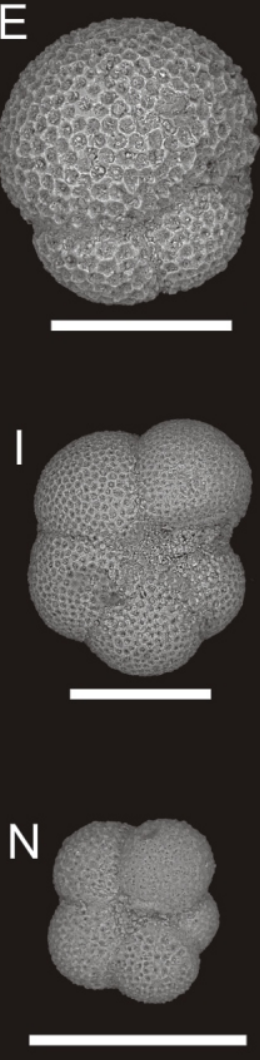

S

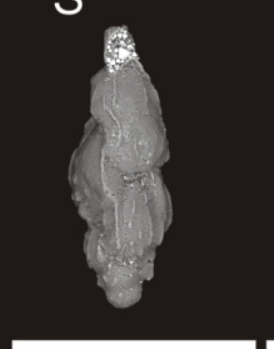

B

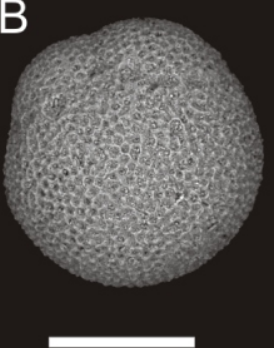

F

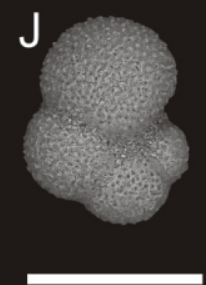

C

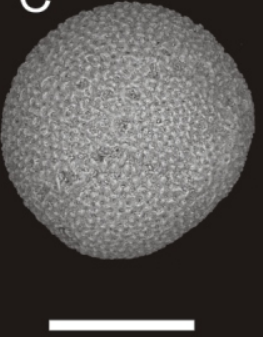

G

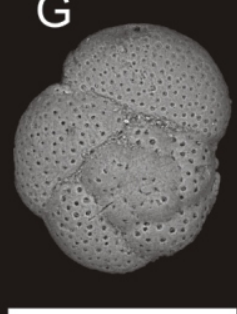

D

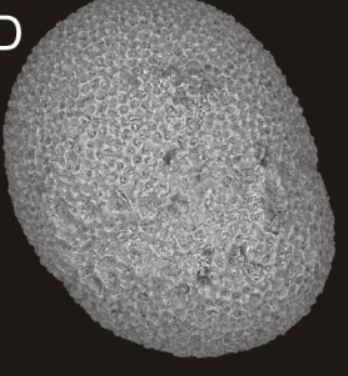

$\mathrm{H}$

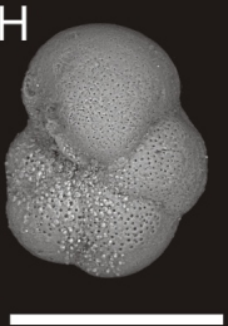

M
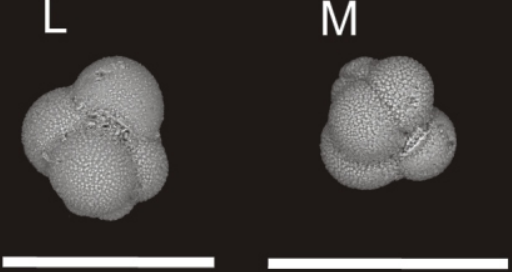

$\mathrm{O}$
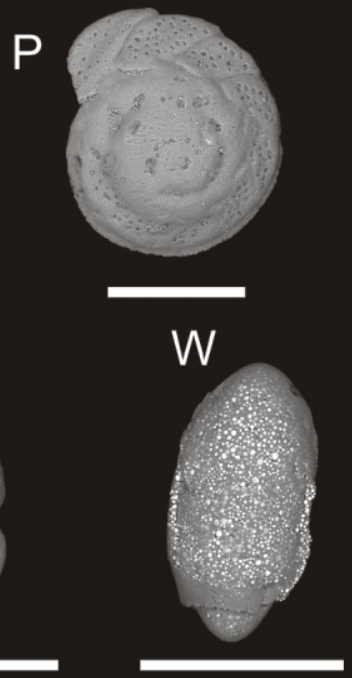

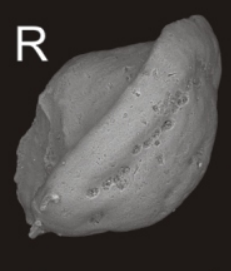

Z
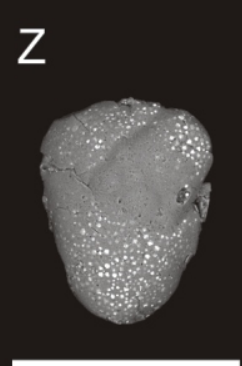

Fig. 7. Foraminifera from Kaczyce K2/07 borehole

Depth 684.0 m A-H: A - Orbulina suturalis Bronnimann; B, C - Praeorbulina glomerosa glomerosa (Blow); D - Praeorbulina transistoria (Blow); E, F - Globigerinoides bisphericus Todd; G, H - Globorotalia bykovae (Aisenstat); I - Paragloborotalia mayeri (Cushman et Ellisor); J - Globigerinella obesa (Bolli); K-M - Globigerina glutinata (Egger); N, O - Globigerina tarchanensis Subbotina et Chutzieva; $\mathbf{P}, \mathbf{R}$ - Cibicidoides conspiciendus Pishvanova; $\mathbf{S}$ - Angulogerina esuriens Hornibrook; depth 650.2 m 19-22: T - Virgulinella pertusa (Reuss); U - Nonionella turgida (Williamson); W - Chilostomella ovoidea Reuss, Z - Allomorphina trigona Reuss 
observed only above the LO of $\mathrm{H}$. ampliaperta. In contrast to the FOs the last common occurrence (LCO) of $H$. waltrans dated at 14.36 Ma (Abdul Azizi et al., 2008) in the Mediterranean region can be used as a synchronous event and defines the top of the MNN5a Subzone (Fornaciari and Rio, 1990) and also the top of the Central Paratethyan Lagenidae Zone. In the Paratethys the LCO of this form was recorded at $14.39 \mathrm{Ma}$ (the Styrian Basin: Hohenegger et al., 2009; Holcová, 2017) which agrees approximately with the dating in the Mediterranean, with which the Central Paratethys was connected at that time.

Based on the occurrence of $H$. waltrans and small reticulofenestrids, C. premacintyrei, $S$. heteromorphus and $P$. multipora, the part of the section studied can be correlated with the lower part of the NN5 Zone sensu Švábenická (2002).

The results obtained support previous calcareous nannoplankton studies from boreholes in the Cieszyn area (Garecka and Olszewska, 1995, 1998; Garecka et al., 1996; Olszewska and Garecka, 1996; Moryc, 2005). In the bottom part of the Skawina Beds in the Zebrzydowice 13 borehole ( $\sim 6 \mathrm{~km}$ E of the Kaczyce K2/07), the NN5 Zone was identified based on the occurrence of $S$. heteromorphus and lack of $H$. ampliaperta (e.g., Martini and Müller, 1986).

Foraminifera. The foraminiferal assemblage recognized in the first sample $(684.0 \mathrm{~m})$ corresponds to the Orbulina suturalis-Praeorbulina glomerosa Zone (according to Cicha et al., 1975; Fig. 8) and can be correlated with the regional IIA and IIB Assemblage Zone (Alexandrowicz, 1963b; Table 1).

Orbulina suturalis Bronnimann has the best stratigraphic value among the foraminifers which occur abundantly in the first sample $(684.0 \mathrm{~m})$. In the oceanic realms, such as the Atlantic, the FO of $O$. suturalis is dated at $15.1 \mathrm{Ma}$ (Wade et al., 2011). In the Mediterranean bio-zonation its FO is astronomically dated at $14.56 \mathrm{Ma}$ (Abdul Aziz et al., 2008), and marks the base of the MMi5a subzone.

The foraminiferal assemblage identified in the sample above $650.2 \mathrm{~m}$ does not contain any index species. The composition of the benthic foraminiferal assemblage, and, primarily, the presence and domination of the species Nonionella turgida (Williamson), Virgulinella pertusa (Reuss), Chilostomella ovoidea Reuss, and Allomorphina trigona Reuss, indicate dysoxic (cf. Peryt, 2013) conditions, which is supported by very frequent specimen pyritisation. A similar assemblage was described from a nearby exposure at Stara Wieś near Bielsko (Porębska-Szotowa in Nowak, 1976). There, the base of the succession was categorized as the Orbulina suturalis Zone (Cicha et al., 1975). Therefore, the foraminiferal assemblage of the $650.2 \mathrm{~m}$ sample probably belongs to the same zone.

According to Hohenegger et al. (2009 with references therein) co-occurrence of the nannoplankton species Helicosphaera waltrans and foraminiferal species Praeorbulina glomerosa glomerosa corresponds to the regional Central Paratethyan Lower Lagenidae Zone (Grill, 1941) meaning that the assemblage from $684.0 \mathrm{~m}$ depth corresponds to this zone (Fig. 8). The Lower Lagenidae Zone (Grill, 1941) ends with the LCO (Last Common Occurrence) of $H$. waltrans (Hohenegger and Wagreich, 2012) dated at 14.357 $\pm 0.004 \mathrm{Ma}$ (Abdul Aziz et al., 2008). According to the radio-isotopic data of the tuffitic horizon $(14.27 \pm 0.03 \mathrm{Ma}$ ) the lowermost part of the Skawina Formation represents, most probably, the Lower Lagenidae Zone the lowermost Upper Lagenidae Zone (Grill, 1941).

\section{AGE OF THE BADENIAN FLOODING}

Regardless of the followed biozonation, the biostratigraphic constraints for the basal Skawina Formation overlap with each other, and with the radio-isotopic age determined (Fig. 8). The ${ }^{40} \mathrm{Ar} /{ }^{39} \mathrm{Ar}$ tuff age $(14.27 \pm 0.03 \mathrm{Ma})$ from $\sim 30 \mathrm{~m}$ above the base of the Skawina Formation is in agreement with the NN5 and MNN5a nannofossil zones determined (Fig. 8).

The occurrence of Orbulina suturalis, Praeorbulina glomerosa glomerosa, Pr. transitoria and Globorotalia bykovae in the Skawina Formation is known from other boreholes in the Carpathians (Garecka et al., 1996 and references therein; Moryc, 2005 and references therein). This indicates that the

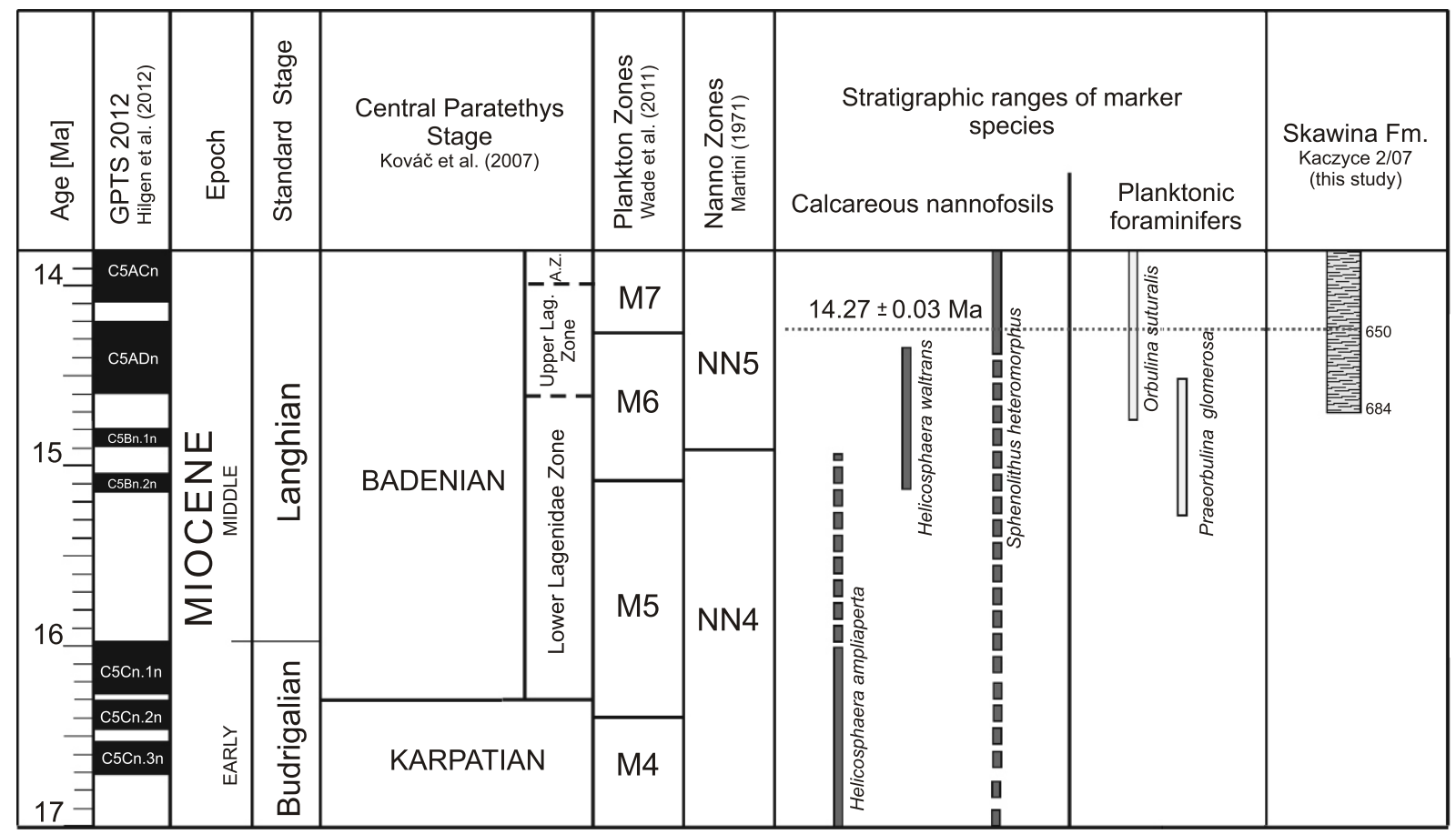

Fig. 8. Correlation of Kaczyce K2/07 borehole to the time scale by biostratigraphic events and the radioisotopic age of the tuffite 
maximum age for the onset of deeper marine deposition in the study area is estimated at $\sim 14.56 \mathrm{Ma}$ (FO O. suturalis, Abdul Aziz et al., 2008).

According to Kováč et al. (2007) there were two early Badenian transgressions in the Central Paratethys. The first transgression is documented by planktonic foraminiferal assemblages with Praeorbulina sicana and Pr. glomerosa within the calcareous nannoplankton NN4 Zone estimated at 16.4-16.2 Ma (e.g., Hohenegger et al., 2009). The second Badenian transgression is characterized by planktonic foraminiferal associations with Praeorbulina circularis and Orbulina suturalis within the nannoplankton NN5 Zone, which should roughly correspond to the age range 14.9-14.6 Ma (Abdul Aziz et al., 2008; laccarino et al., 2011). Our research on foraminifers and calcareous nannoplankton indicates that the study area was affected by the second transgression, sensu Kováč et al. (2007).

This transgression was most likely forced by a combination of tectonics and eustasy; the Mi3b sea level rise ( 14.9 Ma) might have assisted the transgression (Kominz et al., 2008; John et al., 2011). Areas with a similar age for the flooding are reported from many other regions of the Central Paratethys, including the South Slovak basin (Vass, 2002), North Croatian basins (Ćorić et al., 2009) and inner Ukrainian Carpathian Foredeep (e.g., Andreyeva-Grigorovich et al., 1997; Gozhyk et al., 2015).

\section{CORRELATION OF VOLCANIC ASH LAYERS}

Many Miocene sequences of the Carpathian Foredeep contain pyroclastic interbeds (mainly tuffites). They are observed in the Upper Silesia Basin, near Kraków and Wieliczka, as well as along the southern margin of the Holy Cross Mts (e.g. Parachoniak, 1962; Dudek and Bukowski, 2004; Dudek et al. 2004; Bukowski et al., 2010; Bukowski, 2011, 2015). At least two of the pyroclastic layers have a characteristic mineral composition and occupy a stable stratigraphic position regionally. These could be used as lithostratigraphic horizons for the purpose of regional correlation. Alexandrowicz (1997) proposed a "bed" rank for them, recognising them as formal lithostratigraphic units. The first pyroclastic layer occurs in the lower part of the Skawina Formation and contains characteristic foraminiferal assemblages IIA or IIAB (Table 1). The layer's presence was confirmed by a number of profiles collected in the Carpathian Foredeep, e.g. several profiles from Chełmek and Chelm Wielki on the Przemsza River (Parachoniak, 1960; Alexandrowicz and Pawlikowski, 1978) as well as Żory (Alexandrowicz, 1963b). This tuffite horizon is called the Chełmek Tuffite Bed (Alexandrowicz, 1997).

The petrography of the Chelmek Tuffite was described in detail by Parachoniak (1962) and Alexandrowicz and Pawlikowski (1978). The authors identified a similarity with the tuffite collected from borehole Kaczyce K2/07. The specific samples displayed a characteristic high proportion of pyroclastic quartz (which was either absent in other tuffite levels or occurred only in small proportions) and a similar chemical composition of volcanic glass (Appendix 1).

The lithostratigraphic position of the layers situated in the lower part of the clayey deposits of the Skawina Formation are very similar to the previously examined ones in the Brzezówka IG 1 profile, located in the vicinity of Kaczyce K2/07
(3 km SE; Alexandrowicz, 1963b). There, the tuffite layer occurs $\sim 70 \mathrm{~m}$ above the Carboniferous basement, within grey clays with sand intercalations (Schlier facies) and contains a benthic foraminifer assemblage representing the II $A B$ Zone (Alexandrowicz, 1963b) corresponding to the Orbulina suturalis-Praeorbulina glomerosa Zone (Cicha et al., 1975). Considering the respective results and close vicinity of the Kaczyce 2/07 and Brzezówka IG 1 boreholes, the tuffites occurring in both boreholes are most likely of a similar age.

The results of our study allow us to correlate the tuffite from the Kaczyce K2/07 borehole at the level of the Chełmek Tuffite Bed (Alexandrowicz, 1997) and use it for regional correlation and dating. This volcanic ash fall (14.27 $\pm 0.03 \mathrm{Ma})$ coincides in time with a period of intensive extrusive volcanism in the Carpathian area. The onset of this activity, after the first occurrence (FO) of Orbulina suturalis, confirmed by ${ }^{40} \mathrm{Ar} /{ }^{39} \mathrm{Ar}$ dating,

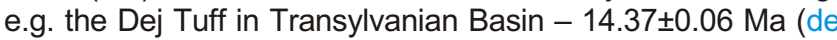
Leeuw et al., 2013), or the tuff from Retznei Quarry in the Styrian Basin: $14.39 \pm 0.12 \mathrm{Ma}$ - sanidine and $14.21 \pm 0.07 \mathrm{Ma}$ biotite (Handler et al., 2006). It is difficult to clearly indicate the location of the eruptive centre. One potential area is the Bükkalja volcanic field in northern Hungary (e.g., Lukács et al., 2009). The last major volcanic event occurred there at $14.1 \pm 0.3 \mathrm{Ma}$ (Harsány ignimbrite, Lukács et al., 2015). Correlation of the tuffite from the Kaczyce K2/07 with the Harsány ignimbrite eruption event is supported also by a similar mineral assemblage involving quartz, the composition of the plagioclases, biotite, sporadic K-feldspar, zircon, allanite and apatite (Lukács et al., 2009).

\section{CONCLUSIONS}

Our radio-isotopic, petrographic and biostratigraphic data of the tuff-bearing lower Skawina Formation from the Kaczyce $\mathrm{K} 2 / 07$ borehole core has provided new insights into the age and correlation of the lower Badenian deposits in the Polish Carpathian Foredeep.

Our biostratigraphic data with Orbulina suturalis and Praeorbulina glomerosa glomerosa show that the basal beds of the Skawina Formation up to the tuffites cover the regional interval of the Lower Lagenidae Zone - lowermost Upper Lagenidae Zone (Grill, 1941). In the overlying tuff, the weighted mean ${ }^{40} \mathrm{Ar} /{ }^{39} \mathrm{Ar}$ age based on sanidine minerals is $14.27 \pm$ $0.03 \mathrm{Ma}$. The mean age based on (partially weathered) biotite minerals from the same sample overlaps with the sanidine age. The ${ }^{40} \mathrm{Ar} /{ }^{39} \mathrm{Ar}$ tuff age is in agreement with the NN5 and MNN5a Zones determined with the calcareous nannofossil Helicosphaera waltrans. The volcanoclastic interval has a characteristic petrography (pyroclastic quartz-rich) and may be used as a lithostratigraphic marker horizon in regional correlation, such as to the very similar Chełmek Tuffite Bed (Alexandrowicz, 1997).

Acknowledgements. We would like to specially thank I. Lipiarski and J. Misiak (Coal Geology Research Group, AGH University of Science and Technology) whose help during collection of the samples was valuable, and R. Elsas (VU University Amsterdam) for assistance in the mineral separation lab. This investigation was supported by the Netherlands Geosciences Foundation (ALW) with funding from NWO through the $\mathrm{VICl}$ grant to $\mathrm{WK}$ and by projects $\mathrm{AGH}$ nos. 11.11.140.320 and 11.11.140.005. 


\section{REFERENCES}

Abdul Aziz, H., Di Stefano, A., Foresi, L.M., Hilgen, F.J., laccarino, S.M., Kuiper, K.F., Lirer, F., Salvatorini, G., Turco, E., 2008. Integrated stratigraphy and ${ }^{40} \mathrm{Ar} /{ }^{39} \mathrm{Ar}$ chronology of early Middle Miocene sediments from DSDP Leg 42A, Site 372 (Western Mediterranean). Palaeogeography, Palaeoclimatology, Palaeoecology, 257: 123-138.

Alexandrowicz, S.W., 1957. Pyroclastic quartz from Tortonian sediments in the Cracow area (in Polish with English summary). Biuletyn Instytutu Geologicznego, 115: 27-61.

Alexandrowicz, S.W., 1963a. Stratigraphy of the Miocene deposits in the Upper Silesian Basin (in Polish with English summary). Prace Instytutu Geologicznego, 39: 1-147.

Alexandrowicz, S.W., 1963b. Sediments of the Lower Tortonian at Brzezówka, near Cieszyn (in Polish with English summary), Kwartalnik Geologiczny, 7 (2): 319-336.

Alexandrowicz, S.W., 1997. Lithostratigraphy of the Miocene deposits in the Gliwice area (Upper Silesia, Poland). Bulletin of the Polish Academy of Science, Earth Sciences, 45: 167-179.

Alexandrowicz, S.W., Pawlikowski, M., 1978. Miocene tuffites from Chełm Wielki on Przemsza River (in Polish with English summary). Kwartalnik Geologiczny, 22 (1): 131-147.

Alexandrowicz, S.W., Garlicki, A., Rutkowski, J., 1982. Podstawowe jednostki litostratygraficzne miocenu zapadliska przedkarpackiego (in Polish). Kwartalnik Geologiczny, 26 (2): 470-471.

Andreyeva-Grigorovič, A.S., Savitskaya, N.A., 2000. Nannoplankton of the Tarkhanian deposits of the Kerch Peninsula (Crimea). Geologica Carpathica, 51: 399-406.

Andreyeva-Grigorovich, A.S., Kulchytsky, Y.O., Gruzman, A.D., Lozynyak, P.Y., Petrashkevich, M.I., Portnyagina, L.O., Ivanina, A.V, Smirnov, S.E., Trofimovich, N., Savitskaya, N., Shvareva, N.J., 1997. Regional stratigraphic scheme of Neogene formations of the Central Paratethys in the Ukraine. Geologica Carpathica, 48: 123-136.

Báldi-Beke, M., 1984. The nannoplankton of the Transdanubian Palaeogene formations (in Hungarian with English summary). Geologica Hungarica, Series Palaeontologica, 43: 3-307.

Bartol, M., 2008. Middle Miocene calcareous nannoplankton of NE Slovenia (western Central Paratethys). Paleontološki Inštitut Ivana Rahovca ZRC SAZU Ljublana: 5-136.

Bogacz, W., Kotarba, M., Krach, J., 1984. Structural features of the coal-bearing strata In the southern part of the Rybnik Coal District (Southern Poland). Annales Societatis Geologorum Poloniae, 54: 361-377.

Bukowski, K., 2011. Badenian saline sedimentation between Rybnik and Dębica based on geochemical, isotopic and radiometric research (in Polish with English summary). Rozprawy i Monografie, 236.

Bukowski, K., 2015. Miocene tuffite levels from the Busko (Młyny) PIG-1 and Kazimierza Wielka (Donosy) PIG-1 boreholes (in Polish with English summary). Biuletyn Państwowego Instytutu Geologicznego, 461: 79-94.

Bukowski, K., de Leeuw, A., Gonera, M., Kuiper, K.F., Krzywiec, P., Peryt, D., 2010. Badenian tuffite levels within the Carpathian orogenic front (Gdów-Bochnia area, Southern Poland): radioisotopic dating and stratigraphic position. Geological Quarterly, 54 (4): 449-464.

Buła, Z., Jura, D., 1983. Litostratygrafia osadów rowu przedgórskiego Karpat w rejonie Śląska Cieszyńskiego (in Polish). Zeszyty Naukowe AGH, Geologia, 9: 5-27.

Cicha, I., Čtyroká, J., Zapletalová, I., Vanova, M., 1975. East Alps and West Carpathian basins: marine zones of benthic foraminifera. In: Biozonal Subdivision of the Upper Tertiary Basins of the Eastern Alps and West Carpathians (ed. I. Cicha): 34-40. Proceedings of the VIth Congress RCMNS, Geol. Surv. Prague.

Cicha, I., Rögl, F., Rupp, Ch., Ctyroka, J., 1998. Oligocene-Miocene foraminifera of the Central Paratethys. Abhandlungen der Senckenbergischen Naturforschenden Gesellschaft, 549.

Ćorić, S., Rögl, F., 2004. Roggendorf-1 borehole, a key-section for Lower Badenian transgressions and the stratigraphic position of the Grund Formation (Molasse Basin, Lower Austria). Geologica Carpathica, 55: 165-178.

Ćorić, S., Švábenická, L., Rögl, F., Petrová, P., 2007. Stratigraphical position of Helicosphaera waltrans nannoplankton Horizon (NN5, Lower Badenian). Joannea - Geologie und Paläontologie, 9: 17-19.

Ćorić, S., Pavelić, D., Rögl, F., Mandic, O., Vrabac, S., 2009. Revised Middle Miocene datum for initial marine flooding of North Croatian Basins (Pannonian Basin System, Central Paratethys). Geologia Croatica, 62: 31-43.

De Leeuw, A., Filipescu, S., Maţenco, L., Krijgsman, W., Kuiper, K., Stoica, M., 2013. Paleomagnetic and chronostratigraphic constraints on the Middle to Late Miocene evolution of the Transylvanian Basin (Romania): implications for Central Paratethys stratigraphy and emplacement of the Tisza-Dacia plate. Global and Planetary Change, 103: 82-98.

Di Stefano, A., Foresi, L.M., Lirer, F., laccarino, S.M., Turco, E., Amore, F.O., Morabito, S., Salvatorini, G., Mazzei, R., Abdul Aziz, H., 2008. Calcareous plankton high resolution bio-magnetostratigraphy for the Langhian of the Mediterranean area. Rivista Italiana di Paleontologia e Stratigrafia, 114: 51-76.

Dudek, K., Bukowski, K., 2004. Badenian pyroclastic level from Gacki in Nida Valley, Carpathian Foredeep, Poland. Special Papers Mineralogical Society of Poland, 24: 141-144.

Dudek, K., Bukowski, K., Heflik, W., 2004. Mineralogical characteristics of the Bochnia Tuff from the Chodenice Beds (Carpathian Foredeep, S Poland). Mineralogia Polonica, 35: 63-78.

Dopita, M., Kumpera, O., 1993. Geology of the Ostrava-Karvina coal-field, Upper Silesian basin, Czech Republic and its influence on mining. International Journal of the Coal Geology, 23: 291-321.

Doktor, M., 1992. Zróżnicowanie gruboklastycznych osadów miocenu na obszarze Śląska Cieszyńskiego (in Polish). Baseny sedymentacyjne: procesy, osady, architektura. II Krajowe Spotkanie Sedymentologów (Wrocław-Sudety, 4-7 IX 1993), Przewodnik: 151.

Doktor, M., 1994. Pozycja i cechy sedymentacyjne zlepieńca dębowieckiego - trzeciorzęd zachodniej części zapadliska przedkarpackiego (in Polish). Sedymentacja normalna, katastroficzna i wyjątkowa. Procesy i produkty. III Krajowe Spotkanie Sedymentologów (Sosnowiec, 12-15 IX 1994): 94-95.

Fodor, L., Jelen, B., Márton, E., Skaberne, D., Čar, J., Vrabec, M., 1998. Miocene-Pliocene tectonic evolution of the Slovenian Periadriatic fault: implications for Alpine-Carpathian extrusion models. Tectonics, 17: 690-709.

Fornaciari, E., Rio, D., 1996. Latest Oligocene to early middle Miocene quantitative calcareous nannofossil biostratigraphy in the Mediterranean region. Micropaleontology, 42: 1-36.

Fornaciari, E., Di Stefano, A., Rio, D., Negri, A., 1996. Middle Miocene quantitative calcareous nannofossils biostratigraphy in the Mediterranean region. Micropaleontology, 42: 37-63.

Garecka, M., Olszewska, B., 1995. Próba korelacji utworów dolnej molasy na zachód od Krakowa na podstawie otwornic nannoplanktonu wapiennego (in Polish). PIG-PIB OK; NAG OK/450: 1-19.

Garecka, M., Olszewska, B., 1998. Biostratigraphy of the early Miocene of the southern Poland based on planktonic foraminifera and calcareous nannoplankton. Przegląd Geologiczny, 46: 712-720.

Garecka, M., Marciniec, P., Olszewska, B., Wójcik, A., 1996. New biostratigraphical data and an attempt of correlation of Miocene deposits under the overthrusted Western Carpathians (in Polish with English summary). Przegląd Geologiczny, 44: 495-501.

Gonera, M., 1997. Miocene foraminiferal assemblage in the Gliwice area (Upper Silesia, Poland). Bulletin of the Polish Academy of Science. Earth Sciences, 45: 97-105.

Gonera, M., 2000. Foraminiferida and palaeoenvironment of the Badenian formations (Middle Miocene) in Upper Silesia (Poland) (in Polish with English summary). Studia Naturae, 48. 
Gonera, M., Bukowski, K., 2012. Isotopic events in the Early/Middle Badenian (Miocene) of the Upper Silesia Basin (Central Paratethys). Geological Quarterly, 56 (3): 561-568.

Gozhyk, P., Semenenko, V., Andreyeva-Grigorovič, A.S., Maslun, N., 2015. The correlation of the Neogene of Centra and eastern Paratethys segments of Ukraine with the International Stratigraphic Chart based on planktonic microfssils. Geologica Carpathica, 66: 235-244.

Grigorovich, A., 2001. Mid-Miocene nannoplankton correlation in the Paratethys. Berichte des Institutes für Geologie und Paläontologie der Karl-Franzens-Universität Graz/Austria, 4: 10-13.

Grill, R., 1941. Stratigraphische Untersuchungen mit Hilfe von Mikrofaunen im Wiener Becken und den benachbarten Molasseanteilen. Oel u. Kohle (Berlin), 37: 595-602.

Hamor, G., Halmai, J., eds., 1988. Neogene palaeogeographic atlas of Central and Eastern Europe. 7 maps. Hungarian Geological Institute, Budapest.

Handler, R., Ebner, F., Neubauer, F., Bojar, A.V., Hermann, S. 2006. ${ }^{40} \mathrm{Ar} /{ }^{39} \mathrm{Ar}$ dating of Miocene tuffs from the Styrian part of the Pannonian Basin: an attempt to refine the basin stratigraphy. Geologica Carpathica, 57: 483-494.

Haq, B.U., Hardenbol, J., Vail, P.R., 1988. Mesozoic and Cenozoic chronostratigraphy and eustatic cycles. SEPM Special Publication, 42: 71-108.

Harangi, S., Lenkey, L., 2007. Genesis of the Neogene to Quaternary volcanism in the Carpathian-Pannonian region: role of subduction, extension, and mantle plume. GSA Special Paper, 418: $67-92$

Hardenbol, J., Thierry, J., Farley, M.B., Jacquin, Th., de Graciansky, P.C., Vail, P.R., 1998. Mesozoic and Cenozoic sequence chronostratigraphic framework of European basins. SEPM Special Publications, 60: 3-13.

Harzhauser, M., Piller, W.E., 2007. Benchmark data of a changing sea - palaeogeography, palaeobiogeography and events in the Central Paratethys during the Miocene. Palaeogeography, Palaeoclimatology, Palaeoecology, 253: 8-31

Hilgen, F.J., Lourens, L.J., Van Dam, J.A. With contributions by Beu, A.G., Boyes, A.F., Cooper, R.A., Krijgsman, W., Ogg J.G., Piller, W.E., Wilson, D.S., 2012. The Neogene Period. In: The Geologic Time Scale 2012 (eds. Gradstein, F.M., Ogg, J.G. Schmitz, M.D. and Ogg, G.M.): 923-978. Elsevier, Amsterdam.

Hohenegger, J., Wagreich, M., 2012. Time calibration of sedimentary sections based on insolation cycles using combined cross-correlation: dating the gone Badenian stratotype (Middle Miocene, Paratethys, Vienna Basin, Austria) as an example. International Journal of Earth Sciences, 101: 339-349.

Hohenegger, J., Rögl, F., Ćorić, S., Pervesler, P., Lire, F., Roetzel, R., Scholger, R., Stingl, K., 2009. The Styrian Basin: a key to the Middle Miocene (Badenian/Langhian) Central Paratethys transgressions. Austrian Journal of Earth Sciences, 102 102-132.

Hohenegger, J., Ćorić, S., Wagreich, M., 2014. Timing of the Middle Miocene Badenian Stage of the Central Paratethys Geologica Carpathica, 65: 55-66.

Holcová, K., 2017. Calcareous nannoplankton and foraminiferal response to global Oligocene and Miocene climatic oscillations: a case study from the Western Carpathian segment of the Central Paratethys. Geologica Carpathica, 68: 207-228.

Horváth, F., 1993. Towards a mechanical model for the formation of the Pannonian basin. Tectonophysics, 226: 333-357.

Horváth, F., Bada, G., Szafián, P., Tari, G., Ádám, A., Cloetingh, S., 2006. Formation and deformation of the Pannonian Basin constraints from observational data. Geological Society Memoirs, 32:191-206.

Horváth, F., Musitz, B., Balázs, A., Végh, A., Uhrin, A., Nádor, A. Koroknai, B., Pap, N., Tóth, T., Wórum, G., 2015. Evolution of the Pannonian basin and its geothermal resources. Geothermics, 53: 328-352.

laccarino, S.M., Di Stefano, A., Foresi, L.M., Turco, E., Baldassini, N., Cascella, A., Da Prato, S. , Ferraro, L. Gennari, R., Hilgen, F.J., Lirer, F., Maniscalco, R., Mazzei, R., Riforgiato, F., Russo, B., Sagnotti, L., Salvatorini, G. Speranza, F., Verducci, M., 2011. High-resolution integrated stratigraphy of the upper Burdigalian-lower Langhian in the
Mediterranean: the Langhian historical stratotype and new candidate sections for defining its GSSP. Stratigraphy, 8: 199-215.

Jachowicz, S., Jura, D., 1987. Genesis of hard coal boulders in sandstones of the Miocene Dębowiec Formation (in Polish with English summary). Kwartalnik Geologiczny, 31 (4): 609-642.

John, C., Karner, G. D., Browning, E., Leckie, M.R., Mateo, Z. Carson, B. Lowery, C., 2011. Timing and magnitude of Miocene eustacy derived from the mixed siliciclastic-carbonate stratigraphic record of the northeastern Australian margin. Earth and Planetary Science Letters, 304: 455-467.

Kominz, M.A., Browning, J.V., Miller, K.G., Sugarman, P.J., Mizintseva, S., Scotese, C.R., 2008. Late Cretaceous to Miocene sea-level estimates from the New Jersey and Delaware coastal plain coreholes: an error analysis. Basin Research, 20: 211-226.

Konior, K., 1981. The role of the Miocene in structure and tectogenesis of marginal zone of the Carpathians in the Cieszyn-Wadowice area (in Polish with English summary). Przegląd Geologiczny, 29: 5-13.

Konior, K., Krach, W., 1965. On the Dębowiec Conglomerates and the Miocene fauna from borehole B4, near Bielsko (in Polish with English summary). Acta Geologica Polonica 15: 39-89.

Koppers, A.A.P., 2002. ArArCALC - software for ${ }^{40} \mathrm{Ar} /{ }^{39} \mathrm{Ar}$ age calculations. Computers \& Geosciences, 28: 605-619.

Kováč, M., Andreyeva-Grigorovich, A., Bajraktarević, Z., Brzobohatý, R., Filipescu, S., Fodor, L., Harzhauser, M., Oszczypko, N., Pavelić, D., Rögl, F., Saftić, B., Sliva, L., Studencka, B., 2007. Badenian evolution of the Central Parathethys sea: paleogeography, climate and eustatic sea level changes. Geologica Carpathica, 58: 579-606.

Kováč, M., Hudáčková, N., Halásová, E., Kováčová, M., Holcová, K., Oszczypko-Clowes, M., Báldi, K., Less, G., Nagymarosy, A., Ruman, A., Klučiar, T., Jamrich, M., 2017a. The Central Paratethys palaeoceanography: a water circulation model based on microfossil proxies, climate, and changes of depositional environment. Acta Geologica Slovaca, 9: 75-114.

Kováč, M., Márton, E., Oszczypko, N., Vojtko, R., Hók, J., Králiková, S., Plašienka, D., Klučiar, T., Hudáčková, N., Oszczypko-Clowes, M., 2017b. Neogene palaeogeography and basin evolution of the Western Carpathians, Northern Pannonian domain and adjoining areas. Global and Planetary Change, 155: 133-154.

Kuciński, T.M., Nowak, W.A., Szotowa, W., 1975. Problem stratygrafii utworw mioceńskichw otworach Bielsko 4 (B4) i Kęty 2 (K2) (in Polish). Kwartalnik Geologiczny, 19 (4): 963-964.

Kuiper, K.F., Deino, A., Hilgen, F.J., Krijgsman, W., Renne, P.R., Wijbrans, J.R., 2008. Synchronizing rock clocks of Earth history. Science, 320: 500-504

Lee, J.Y., Marti, K., Severinghaus, J.P., Kawamura, K., Yoo, H.S., Lee, J.B., Kim, J.S., 2006. A redetermination of the isotopic abundances of atmospheric Ar. Geochimica et Cosmochimica Acta, 70: 4507-4512.

Lukács, R., Harangi, S., Mason, P., Ntaflos, T., 2009. Bimodal pumice populations in the 13.5 Ma Harsány ignimbrite, Bükkalja Volcanic Field, Northern Hungary: syn-eruptive mingling of distinct rhyolitic magma batches? Central European Geology, 52: 51-72.

Lukács, R., Harangi, Sz., Bachmann, O., Guillong, M., Danisik, M., Buret, Y., von Quadt, A., DunkI, I., Fodor, L., Śliwinski, J., Soós, I., Szepesi, J., 2015. Zircon geochronology and geochemistry to constrain the youngest eruption events and magma evolution of the Mid-Miocene ignimbrite flare-up in the Pannonian Basin, eastern central Europe. Contributions of Mineralogy and Petrology, 170: 1-26.

Martini, E., 1971. Standard Tertiary and Quaternary calcareous nannoplankton zonation. Proceedings of the II Planktonic Conference, Roma 1970: 264-785.

Martini, E., Müller, C., 1986. Current Tertiary and Quaternary calcareous nannoplankton stratigraphy and correlations. Newsletters on Stratigraphy, 16: 99-112.

Mazzolki, S., Helman, K., 1994. Neogene patterns of relative plate motion for Africa-Europe: some implications for recent central Mediterranean tectonics. International Journal of Earth Sciences, 83: 464-468. 
Melinte-Dobrinescu, M., Stoica, M., 2014. Badenian calcareous nannofossil fluctuation in the eastern Carpathians: palaeoenvironmental significance. Acta Palaeontologica Romaniae, 9: 47-57.

Min, K.W., Mundil, R., Renne, P.R., Ludwig, K.R., 2000. A test for systematic errors in Ar-40/Ar-39 geochronology through comparison with $\mathrm{U} / \mathrm{Pb}$ analysis of a 1.1-Ga rhyolite. Geochimica et Cosmochimica Acta, 64: 73-98.

Moryc, W., 2005. Development of research on Western Carpathian Miocene deposits in the Bielsko-Kraków (in Polish with English summary). Geologia, Kwartalnik AGH, 31: 5-73.

Ney, R., Burzewski, W., Bachleda, T., Górecki, W., Jakóbczak, K., Słupczyński, K., 1974. Outline of paleogeography and evolution of lithology and facies of Miocene layers on the Carpathian Foredeep (in Polish with English summary). Prace Geologiczne, 82: 1-65.

Nowak, W., 1976. The occurrence of Teschenite rocks in the Miocene of Stara Wieś (Karpaty Bielskie) (in Polish with English summary). Kwartalnik Geologiczny, 20 (1): 105-122.

Olszewska, B., Garecka, M., 1996. Foraminifer and nannoplankton biostratigraphy of the lower Miocene of the Carpathian Foredeep. Przegląd Geologiczny, 44: 1049-1053.

Oszczypko, N., Oszczypko-Clowes, M., 2003. The Aquitanian marine deposits in the basement of Polish Western Carpathians and its palaeogeographical and palaeotectonic implications. Acta Geologica Polonica, 53: 101-122.

Oszczypko, N., Oszczypko-Clowes, M., 2011. Stages of development in the Polish Carpathian Foredeep basin. Central European Journal of Geoscience, 4: 138-162.

Oszczypko, N., Krzywiec, P., Popadyuk, I., Peryt, T., 2006 Carpathian Foredeep Basin (Poland and Ukraine): its sedimentary, structural, and geodynamic evolution. AAPG Memoir, 84: 293-350.

Papp, A., Cicha, I., Seneš, J., Steininger, F., eds., 1978. M4 Badenien (Moravien, Wielicien, Kosovien). Chronostratigraphie und Neostratotypen, Miozän der Zentralen Paratethys. 6. VEDA, Bratislava.

Parachoniak, W., 1960. Miocene tuffites in the vicinity of Lędziny (the Upper Silesian Basin) (in Polish with English summary). Biuletyn Instytutu Geologicznego, 155: 107-118.

Parachoniak, W., 1962. Miocene pyroclastic deposits In the foreland of the Polish Carpathians (In Polish with English summary). Prace Geologiczne, 11: 5-77.

Pécskay, Z., Lexa, J., Szakács, A., Seghedi, I., Balogh, K., Konecny, V., Zelenka, T., Kovac, M., Póka, T., Fülöp, A., Márton, E., Panaiotu, C., Cvetkovic, V., 2006. Geochronology of Neogene magmatism in the Carpathian arc and intra-Carpathian area. Geologica Carpathica, 57: 511-530.

Pettijohn, F.J., 1949. Sedimentary Rocks. Harper and Brothers, New York

Peryt, D., 1997. Calcareous nannoplankton stratigraphy of the Middle Miocene in the Gliwice area (Upper Silesia, Poland). Bulletin of the Polish Academy of Science. Earth Sciences, 45: 119-131.

Peryt, D., 2013. Foraminiferal record of the Middle Miocene climate transition prior to the Badeniansalinity crisis in the Polish Carpathian Foredeep Basin (Central Paratethys). Geological Quarterly, 57 (1): 141-164.

Phillips, D., Matchan, E.L., 2013. Ultra-high precision ${ }^{40} \mathrm{Ar} /{ }^{39} \mathrm{Ar}$ ages for Fish Canyon Tuff and Alder Creek Rhyolite sanidine: new dating standards required? Geochimica et Cosmochimica Acta, 121: 229-239.

Picha, F., J., Stranik, Z., Krejci, O., 2006. Geology and hydrocarbon resources of the Outer Western Carpathians and their foreland, Czech Republic. AAPG Memoir, 84: 49-175.

Piller, W.E., Harzhauser, M., Mandic, O., 2007. Miocene Central Paratethys stratigraphy - current status and future directions. Stratigraphy, 4: 151-168.

Rögl, F., 1996. Stratigraphic correlation on the Paratethys Oligocene and Miocene. Mitteilungen der Gesellschaft der Geologie und Bergbaustudenten in Österreich, 41: 65-73.
Rögl, F., 1998. Palaeogeographic considerations for Mediterranean and Paratethys seaways (Oligocene to Miocene). Annalen des Naturhistorischen Museums in Wien, 99 (A): 279-310.

Rögl, F., 1999. Mediterranean and Paratethys. Facts and hypotheses of an Oligocene to Miocene paleogeography (short overview). Geologica Carpathica, 50: 339-349.

Rögl, F., Steininger, F.F., 1983. Vom Zerfall der Tethys zu Mediterran und Paratethys. Die Neogene Paläogeographie und Palinspastik des zirkum-mediterranen Raumes. Annalen des Naturhistorischen Museums Wien, 85 (A): 135-163.

Rögl, F., Steininger, F.F., 1984. Neogene Paratethys, Mediterranean and Indo-Pacific Sea ways. In: Fossils and Climate (ed. P Branchley): 171-200. Wiley.

Rögl, F., Ćorić, S., Hohenegger, J., Pervesler, P., Roetzel, R., Scholger, R., Spezzaferri, S., Stingl, K., 2006. The Styrian tectonic phase - a series of events at the Early/Middle Miocene boundary revised and stratified in the Styrian Basin. Geophysics Research Abstracts, 8, 10733, 3 p.

Sahy, D., Condon, D.J., Terry, Jr., D.O., Fischer, A.U., Kuiper, K.F., 2015. Synchronizing terrestrial and marine records of environmental change across the Eocene-Oligocene transition. Earth and Planetary Science Letters, 427: 171-182.

Sant, K., Palcu, D.V., Mandic, O., Krijgsman, W., 2017. Changing seas in the Early-Middle Miocene of Central Europe: a Mediterranean approach to Paratethyan stratigraphy. Terra Nova, 29: 273-281.

Seneš, J., 1961. Paläogeographie des westkarpatischen Raumes in Beziehung zur übrigen Paratethys im Miozän. Geologické Práce, 60: 159-195.

Steininger, F.F., Seneš, J., Kleeman, K., Rögl, F., eds., 1985. Neogene of the Mediterranean Tethys and Paratethys. Stratigraphic correlation tables and sediment distribution maps. Univ. Vienna Inst. Paleont.

Stille, H., 1924. Grundfragen der vergleichenden Tektonik. Gebrüder Bornträger, Berlin: 1-443.

Szabó, C., Harangi, S., Csontos, L., 1992. Review of Neogene and Quaternary volcanism of the Carpathian-Pannonian region. Tectonophysics, 208: 243-256.

Ślączka A., 1977. Rozwój osadów miocenu z otworu wiertniczego Sucha IG-1 (in Polish). Kwartalnik Geologiczny, 21 (2): 405-406.

Švabenická, L., 2000. Helicosphaera waltrans in the Carpathian foredeep, Central Paratethys and its biostratigraphic and palaeogeographic significance. Journal of Nannoplankton Research, 22: 145-146.

Švábenická, L., 2002. Calcareous nannofossils of the upper Karpatian and Lower Badenian deposits in the Carpathian Foredeep, Moravia (Czech Republic). Geologica Carpathica, 53: 197-210.

Theodoridis, S., 1984. Calcareous nannofossil biozonation of the Miocene and revision of the helicoliths and discoasters. Utrecht Micropaleontological Bulletins, 32.

Tołwiński, K., 1950. The Carpathian marginal region (in Polish with English summary). Acta Geologica Polonica, 1: 13-35.

Tomanová-Petrová, P., Švábenická, L., 2007. Lower Badenian biostratigraphy and paleoecology: a case study from the Carpathians Foredeep (Czech Republic). Geologica Carpathica, 58: 333-352.

Vass D. 2002. Lithostratigraphy of Western Carpathians: Neogene and Buda Paleogene (in Slovak). Štŕny geologický ústav Dionýza Štúra, Bratislava.

Wade, B.S., Pearson, P.N., Berggren, W.A., Heiko, P., 2011. Review and revision of Cenozoic tropical planktonic foraminiferal biostratigraphy and calibration to the Geomagnetic Polarity and Astronomical Time Scale. Earth-Science Reviews, 104: 111-142.

Wagner, M., 1983. Petrological character of bituminous coal from the Mottled Sediments (Upper Carboniferous), southern part of Rybnik Coal District (in Polish with English summary). Zeszyty Naukowe AGH, Geologia, 9: 87-106.

Young, J., 1998. Neogene. In: Calcareous Nannofossils Biostratigraphy (ed. P.R. Bown): 225-265. Kluwer Academic Publishers, Dordrecht. 